\title{
Urban nature conservation: vegetation of natural areas in the Potchefstroom municipal area, North West Province, South Africa
}

\author{
S.S. Cilliers, E. van WyK and G.J Bredenkamp
}

Cilliers, S.S., E. Van Wyk and G.J Bredenkamp. 1999. Urban nature conservation: vegetation of natural areas in the Potchefstroom municipal area, North West Province, South Africa. Koedoe 42(1): 1-30. Pretoria. ISSN 0075-6458.

This study on the natural and degraded natural vegetation of natural areas in the Potchefstroom Municipal Area, forms part of a research programme on spontaneous vegetation in urban open spaces in the North West Province, South Africa. Using a numerical classification technique (TWINSPAN) as a first approximation, the classification was refined by applying Braun-Blanquet procedures. The result is a phytosociological table from which 6 plant communities were recognised, which are subdivided in sub-communities and variants, resulting in 18 vegetation units. Some of these vegetation units are similar to communities described previously in natural areas. The presence of degraded natural communities suggests huge anthropogenic influences in certain areas. An ordination (DECORANA) scatter diagram shows the distribution of the plant communities along gradients which could be related to vegetation structure, altitude, soil depth, rockiness of soil surface, wetness or dryness of the habitat and number of introduced species. This study contributes to the compilation of a guideline for a conservation orientated management plan for the area, but also created a wealth of new knowledge of the reaction of indigenous plant species under disturbed conditions.

Key words: Braun-Blanquet, DECORANA, habitat fragmentation, MEGATAB, nature conservation, plant communities, TURBOVEG, TWINSPAN.

S.S. Cilliers and E. Van Wyk, School for Environmental Sciences and Development, Section Botany, Potchefstroom University for C.H.E., Potchefstroom, 253I Republic of South Africa; G.J Bredenkamp, Department of Botany, University of Pretoria, Pretoria, 0002 Republic of South Africa.

\section{Introduction}

Urbanisation, which is characteristic of a growing human population, contributes to the degradation of urban biospheres, but may also lead to the degeneration of the quality of life for future generations living in these areas. Conservation of open spaces with natural and semi-natural vegetation is constantly in competition with urban development. These open spaces can be regarded as constantly changing environments (Spellerberg 1992), because fragmentation of previously intact natural environments is one of the most devastating results of urbanisation. Fragmentation may cause the potential loss of habitat for some species, the isolation of other species on natural remnants within the urban environment, and the total extinction of certain plant species (Wood et al. 1994).
During the past 30 years, urban open spaces have been the subject of many studies in Europe (Pyšek 1995). The focus was placed, amongst other aspects, on urban vegetation research. Results of these studies have been exceptionally useful for urban land management and urban nature conservation purposes (Henke \& Sukopp 1986; Pyšek 1995).

Although the importance of vegetation studies in and around urban environments in South Africa is realised, as studies by Poynton \& Roberts (1985), Roberts \& Poynton (1985) and Cohen \& Hugo (1986) suggested, relatively few vegetation analyses have been done on natural areas in cities. Habitat fragmentation due to urbanisation has resulted in the extinction or near extinction of many plant species in The Cape Metropolitan Area (Wood et al. 1994). A 


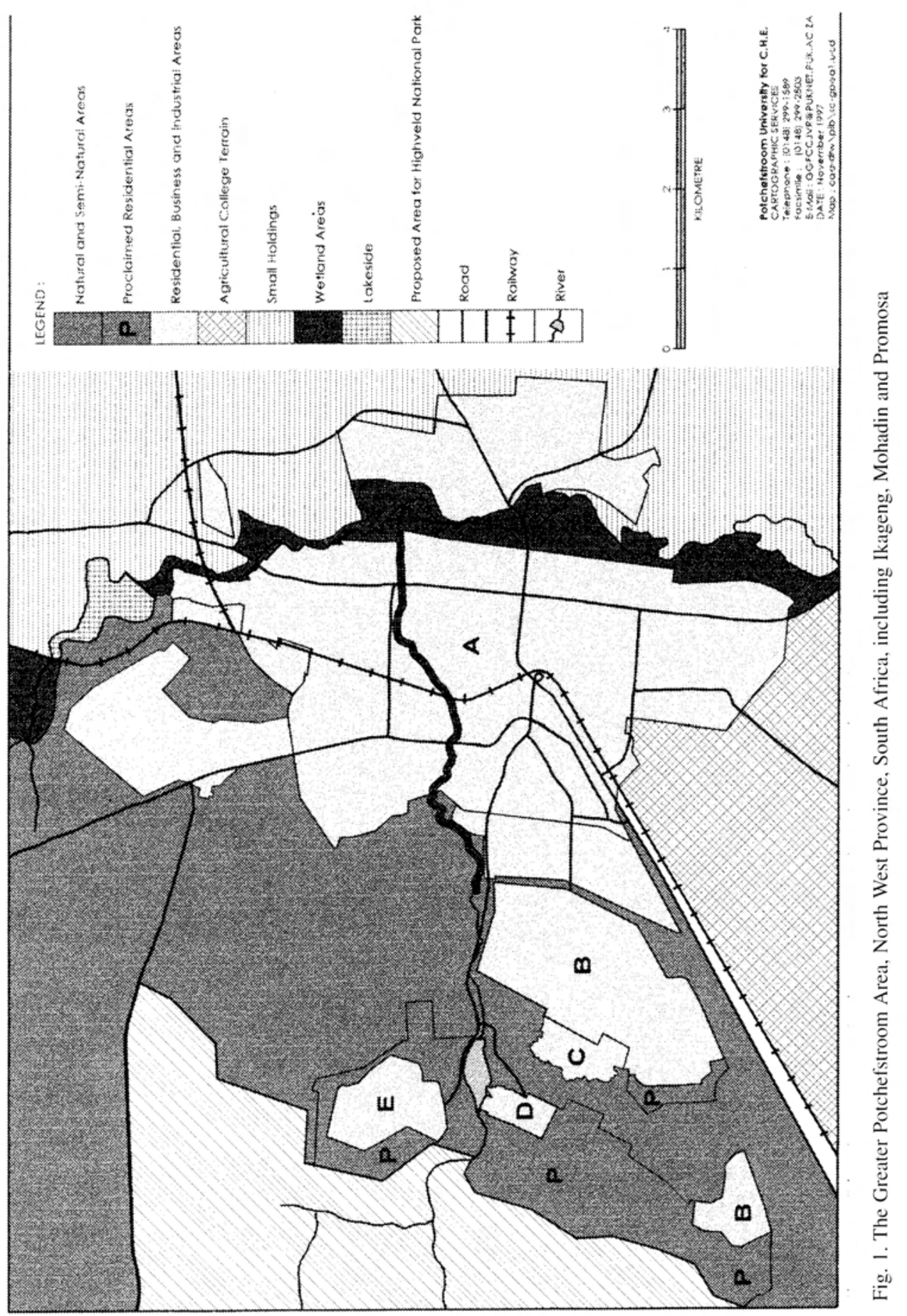


number of related studies on fragmented natural areas in the Fynbos Biome such as those of Cowling \& Bond (1991), McDowell et al. (1991) and Rebelo \& Siegfried (1992) can be regarded as important contributions, all supporting conservation of these floristically rich areas which are also included in the urban environment. The floristic classification of the vegetation in the municipal area of Durban (Roberts 1993a) which served as one of the motivations for the development of the Durban Metropolitan Open Space System (D'Moss) (Roberts 1993b) is another study worth mentioning.

Cohen \& Hugo (1986) stated the importance of conservation outside officially designated nature reserves, such as urban open spaces, and specifically mentioned the poor conservation status of the Grassland Biome. The realisation of the need to determine the location and extent of major vegetation types in the Grassland Biome (Mentis \& Huntley 1982) has resulted in a number of studies on this subject. Important contributions such as those by Bredenkamp et al. (1989), Bezuidenhout \& Bredenkamp (1991), Kooij et al. (1992) and Fuls et al. (1993) are a few examples. The vegetation of disturbed areas in and around urban environments was, however, not addressed by any of these studies.

The recent study of Van Wyk et al. (1997) on the fragmented hills and ridges in Klerksdorp is one of the first attempts to classify and describe the vegetation of natural fragmented areas inside urban environments in the Grassland Biome. Although these fragmented areas were disturbed, it is still in a relatively natural state and should be conserved, but because of a combination of some unique anthropogenic influences, careful management and rehabilitation of some of the communities are required (Van Wyk et al., 1997). Disturbed areas such as roadside verges (Cilliers 1998), railway reserve areas (Cilliers \& Bredenkamp 1998), vacant lots (Cilliers \& Bredenkamp in press a), intensively managed sites (Cilliers \& Bredenkamp in press b) and wetlands (Cilliers et al. 1998) were recently studied in the Potchefstroom municipal area.
The degree of degradation and the conservation status of the natural areas in and around Potchefstroom are not known. Planning and management programmes should be based on accurate floristic studies (Roberts 1993a) and the main aim of the present study is, therefore, to identify, classify and describe the vegetation types of these natural areas. The correlation of the vegetation types with a range of environmental parameters, as well as direct and indirect human influences and a comparison with the vegetation of surrounding natural areas (Bredenkamp et al. 1989; Bezuidenhout \& Bredenkamp 1991; Bezuidenhout et al. 1994a, 1994b, 1994c and 1994d), are also included in the study. The present study forms part of an extensive research programme on vegetation in a number of cities in the North West Province, South Africa, with the ultimate aim of a phytosociological and syntaxonomical synthesis.

\section{Study area}

This study was conducted in natural and semi-natural areas inside the Potchefstroom Municipal Area. The study area included the city of Potchefstroom, Promosa, Mohadin and Ikageng with its suburbs and informal housing settlements (Fig. 1). Potchefstroom is situated between $27^{\circ} 04^{\prime} \mathrm{E}-27^{\circ} 07^{\prime} \mathrm{E}$ and $26^{\circ} 40^{\prime} \mathrm{S}-26^{\circ} 44^{\prime} \mathrm{S}$. The fragmented natural areas inside the city are distinguished from the intensively managed sites (Cilliers \& Bredenkamp in press b) on the basis of type and frequency of management practises as well as the type and intensity of other human disturbances.

Potchefstroom is situated in the summer rainfall region of South Africa and the average rainfall is more than $600 \mathrm{~mm}$ per annum. While the winters are severely frosty, the summer temperatures are high. The mean maximum monthly temperature is usually higher than $32^{\circ} \mathrm{C}$ during October to January, while the mean minimum monthly temperatures are below $-1{ }^{\circ} \mathrm{C}$ during May to September (Weather Bureau 1988).

According to a land type classification system based upon terrain form, soil pattern and 
climate the major part of the study area is described as the $\mathrm{Bc}$ land type (Land Type Survey Staff 1984). The soil of this land type is mainly derived from quartzite and shales, while the geology represents the Ventersdorp Supergroup and Transvaal Sequence (SACS 1980). Low to prominent quartzite ridges sometimes dissect the flat to undulating plains of this land type. The western part of the study area where Ikageng, Mohadin, and Promosa are situated (Fig. 1), can be described as the Fb land type. The hilly and rocky terrain occupied by this land type is mostly high lying (1372-1676 m above sea level) and is regarded as a conspicuous part in the western Transvaal landscape by Bezuidenhout et al. (1994c). The main rock types of the $\mathrm{Fb}$ land type are shale, slate and quartzite of the Pretoria Group with interlayered diabase sills and Hekpoort lava. The quartzite forms the crests and escarpments in the landscape while the footslopes are usually covered by mixed colluvium. The midslopes and drainage lines are on shales and slate (Land Type Survey Staff 1984; Bezuidenhout et al. 1994c).

Potchefstroom is situated in the Grassland Biome (Rutherford \& Westfall 1994) and more specifically in the Dry Sandy Highveld Grassland (Bredenkamp \& Van Rooyen 1996). In a comprehensive syntaxonomical and synecological study of the western Transvaal Grasslands, Bezuidenhout (1993) and Bezuidenhout et al. (1994a) identified five phytosociological classes. Three of the five classes, namely the Eragrostido racemosae-Trachypogonetea spicati, the Rhoo leptodictyae-Acacietea caffrae and the Grewio flavae - Acacietea karroo are probably represented in the study area. Some vegetation types in fragmented natural and seminatural areas inside Potchefstroom belong to classes which are not described at this stage.

\section{Methods}

The Potchefstroom Municipal Area was stratified in different land-use areas. The current study include areas which are not covered by the studies on railway reserve areas; vacant residential, commercial and industrial lots; intensively managed sites such as pavements and parks, the Mooi River wetland system and roadside verges; (Cilliers 1998; Cilliers \& Bredenkamp 1998; Cilliers et al. 1998 and Cilliers \&
Bredenkamp in press $\mathrm{a}, \mathrm{b}$ ). Open areas with no specific use such as grassland and woodland areas, which are connected to the same areas in the natural environment surrounding the city, and natural fragmented areas were investigated in this study. The approach of Bezuidenhout (1993) was followed for further stratification, namely recognition of the terrain types with topographical positions such as crest (1), scarp (2), midslope (3), footslope (3a), bottomlands (4) and floodplains (5) (Land Type Survey Staff 1984) (Fig. 2).

Relevés were compiled in 78 sample plots in the study area representing terrain types and local disturbed areas. Plot sizes were fixed at $16 \mathrm{~m}^{2}$ for grassland and $100 \mathrm{~m}^{2}$ for woody vegetation in accordance to Bredenkamp \& Theron (1978). Cover-abundance values of all species present, were allocated according to the Braun-Blanquet scale, as given by Mueller-Dombois \& Ellenberg (1974). Height and canopy cover averages for the tree, shrub and herbaceous strata were given for each individual community. Differentiation between trees and shrubs were based on definitions proposed by Edwards (1983). Habitat parameters recorded, included soil depth, soil form (Soil Classification Work Group 1991), land type, terrain type, rock type and rockiness of the soil surface (Figs. 3 \& 4) At each sample plot the presence and intensity of direct and indirect human influences, such as mowing, weeding, trampling, overgrazing, cutting and gathering of wood, encroachment or invasion from gardens or other natural areas, dumping of garden and other refuse and other disturbances such as uncontrolled burning and soil excavations (Figs. $3 \& 4$ ) were noted as far as possible. If the effect of any other type of disturbance is known, it was noted as well. The percentages of therophytes and introduced species were recorded as an indication of the degraded state of each vegetation type. Although a life-form classification was not followed in this study, the use of the term therophyte is in accordance to Raunkiaer's lifeform classification system (Raunkiaer 1937).

The TURBOVEG programme (Hennekens 1996a) and the TWINSPAN classification algorithm (Hill 1979a) were used for capture, processing, and presentation of phytosociological data, and subsequently Braun-Blanquet procedures were implemented to refine these results. The result of the final classification is presented in a phytosociological table (Table 1) which was compiled by a visual editor for phytosociological tables, MEGATAB (Hennekens 1996b). Introduced species are clearly marked in the table, as well as those species present in ruderal communities (Cilliers 1998) in the study area. The occurrence of each species in a specific stratum is indicated with a symbol, namely $\mathrm{tl}$ for a high tree layer (> $10 \mathrm{~m}), \mathrm{t} 2$ for an intermediate tree layer $(5-10 \mathrm{~m}), \mathrm{t} 3$ for a low tree layer $(<5 \mathrm{~m}), \mathrm{s} 1$ for a high shrub layer $(>2 \mathrm{~m}), \mathrm{s} 2$ for a low shrub layer $(<2 \mathrm{~m})$ and $\mathrm{hl}$ for a herbaceous layer, in the phytosociological table. In some cases the same species occur in more than one 
stratum in different communities, for example in an intermediate tree layer or in a high shrub layer, and are indicated as such in Table 1. Species which were only encountered a few times during the study and which have relatively low cover abundance values are not included in the phytosociological tables, but lists of these species appear in Cilliers (1998). In the phytosociological table (Table 1) two different numbering systems are used for the relevés, namely a relevé number which starts at 1 and indicates the relevé numbers which were used in this particular study and a TURBOVEG number which indicates the unique relevé number in the South African phytosociological data base. An ordination algorithm, DECORANA (Hill 1979b) was also applied to the floristic data to determine possible environmental and disturbance gradients.

Taxa names conform to those of Arnold \& De Wet (1993), but are updated to November 1996 according to the PRECIS floristic data base of South Africa, managed by the National Botanical Institute in Pretoria. Formal syntaxonomy was not applied in this study, it will follow after completion of the analyses and synthesis of the different land use types in the urban area of Potchefstroom. Formal syntaxa which were referred to in this discussion were already described by other authors. The names of these formal syntaxa were used as they were pub- lished without any attempt to validate invalid names or to correct any typographical errors.

\section{Results and discussion}

\section{Classification}

From the phytosociological table (Table 1) the following six communities, 12 sub-communities and seven variants were recognised:

\section{Vangueria infausta - Rhus pyroides Shrubland Community}

\section{Rhus leptodictya - Acacia caffra Woodland Community}

\subsection{Dombeya rotundifolia Woodland Sub-community}

2.2 Vangueria infausta Woodland Subcommunity

2.3 Acacia karroo - Acacia caffra Woodland Sub-community

\begin{tabular}{|c|c|c|c|c|c|c|c|c|c|c|c|c|c|c|}
\hline $\begin{array}{l}\text { Natural and } \\
\text { degraded } \\
\text { natural } \\
\text { communities }\end{array}$ & 2.3 .2 & $\begin{array}{l}2.1 \\
5.1\end{array}$ & 2.2 & 5.2 & $\begin{array}{l}2.3 .1 \\
2.3 .2\end{array}$ & $\begin{array}{l}2.3 .2 \\
2.3 .3\end{array}$ & $\begin{array}{l}4.1 .1 \\
4.1 .2 \\
3.3 .1 \\
3.3 .2\end{array}$ & 4.2 & 4.4 & 6 & $\begin{array}{l}3.2 \\
4.2\end{array}$ & $\begin{array}{l}3.3 \\
3.3 .1 \\
3.3 .2 \\
4.1 .1 \\
4.1 .2\end{array}$ & $\begin{array}{l}3.1 \\
5.1\end{array}$ & $\begin{array}{l}1 \\
5.1\end{array}$ \\
\hline \multicolumn{15}{|l|}{$1676 \mathrm{~m}$} \\
\hline \multicolumn{15}{|l|}{$1510 \mathrm{~m}$} \\
\hline \multicolumn{15}{|l|}{$1370 \mathrm{~m}$} \\
\hline $\begin{array}{l}\text { Specific } \\
\text { location }\end{array}$ & \multicolumn{6}{|c|}{$\begin{array}{l}\text { City margin, but between Ikageng, } \\
\text { Promosa and Mohadin }\end{array}$} & $\begin{array}{l}\text { City } \\
\text { marg. }\end{array}$ & $\begin{array}{l}\text { Inner } \\
\text { city }\end{array}$ & $\begin{array}{l}\text { City } \\
\text { marg. }\end{array}$ & & $\begin{array}{l}\text { nner } \\
\text { sity }\end{array}$ & \multicolumn{3}{|c|}{ City margin } \\
\hline $\begin{array}{l}\text { Terrain } \\
\text { types (in text) }\end{array}$ & 4 & 2 & 1 & 1 & 3 & $3 a$ & \multicolumn{2}{|l|}{4} & 5 & \multicolumn{3}{|c|}{4} & $3 a$ & 3 \\
\hline Soil forms & $\begin{array}{l}\mathrm{Hu} \\
\mathrm{Gs}\end{array}$ & $\begin{array}{l}\text { Ms } \\
\text { Rk }\end{array}$ & $\begin{array}{l}\text { Ms } \\
\text { Rk }\end{array}$ & $\begin{array}{l}\text { Ms } \\
\text { Gs }\end{array}$ & $\begin{array}{l}\mathrm{Gs} \\
\mathrm{Hu}\end{array}$ & $\begin{array}{l}\mathrm{Hu} \\
\mathrm{Gs}\end{array}$ & $\begin{array}{l}\mathrm{Hu} \\
\mathrm{Va}\end{array}$ & $\begin{array}{l}\mathrm{Hu} \\
\mathrm{Va} \\
\mathrm{Wb}\end{array}$ & $\mathrm{Va}$ & \multicolumn{3}{|c|}{$\begin{array}{l}\mathrm{Hu} \\
\mathrm{Va}\end{array}$} & $\begin{array}{l}\mathrm{Hu} \\
\mathrm{Gs}\end{array}$ & $\begin{array}{l}\text { Ms } \\
\text { Rk }\end{array}$ \\
\hline
\end{tabular}

Fig. 2. The location of the natural and degraded natural communities on the topographical terrain types in natural and semi-natural areas of the Potchefstroom municipal area, North West Province, South Africa (All numbers are explained in text. Abbreviations of soil forms: $\mathrm{Hu}=$ Hutton, Gs = Glenrosa, $\mathrm{Ms}=\mathrm{Mispah}$, Va $=$ Valsrivier, $\mathrm{Wb}=$ Witbank, and Rk refers to rock) (Taken partly from Bezuidenhout et al.1994c). 


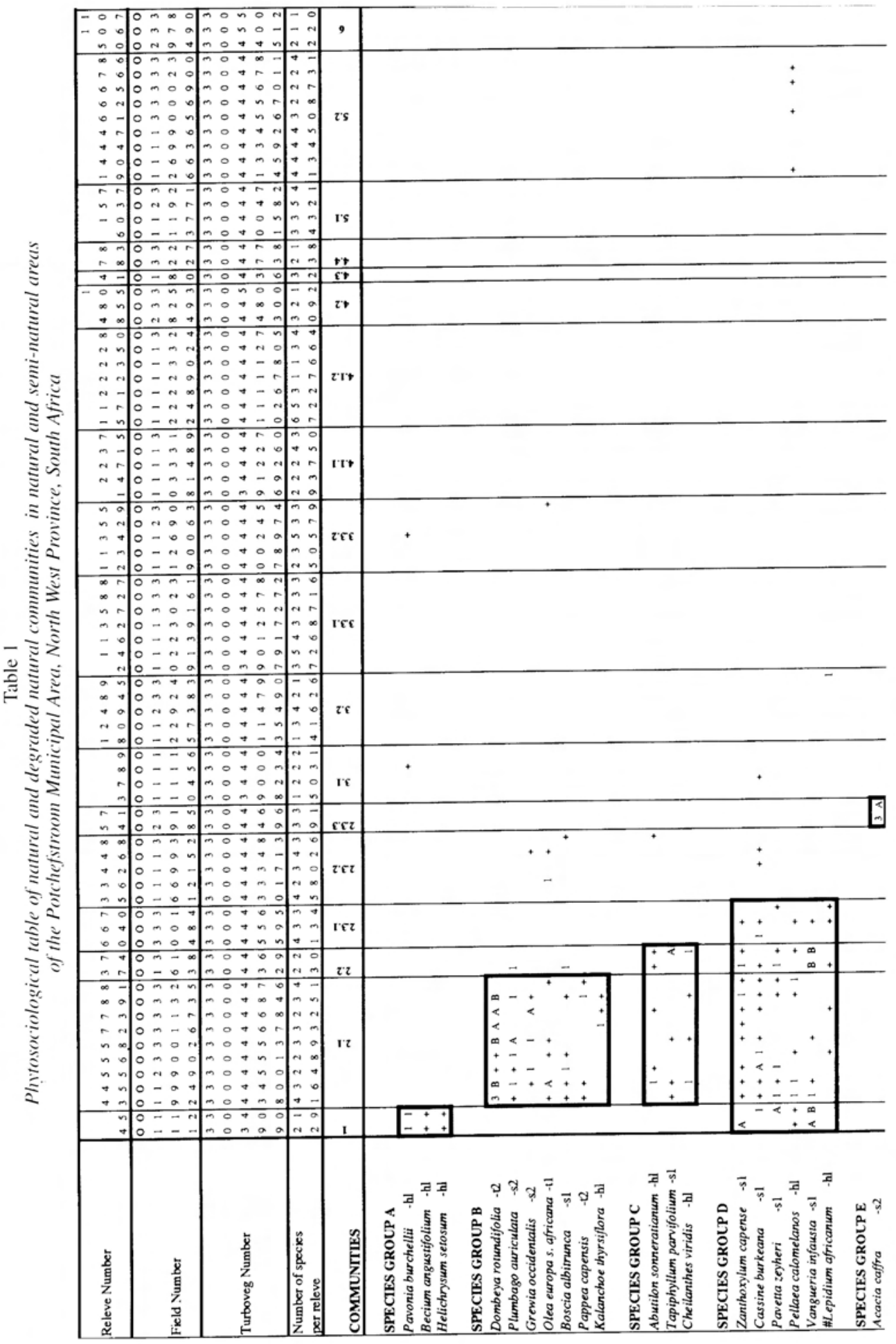




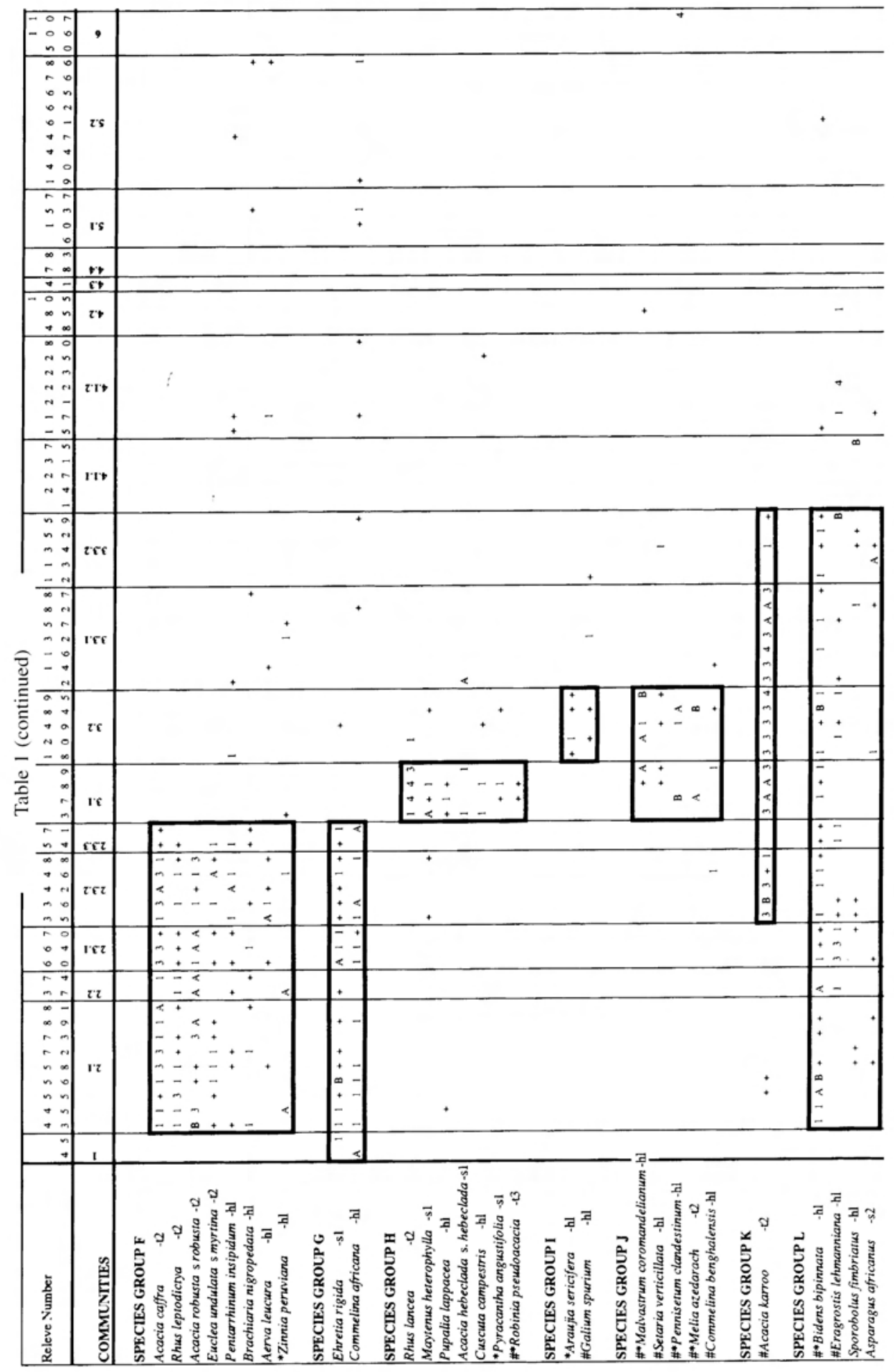




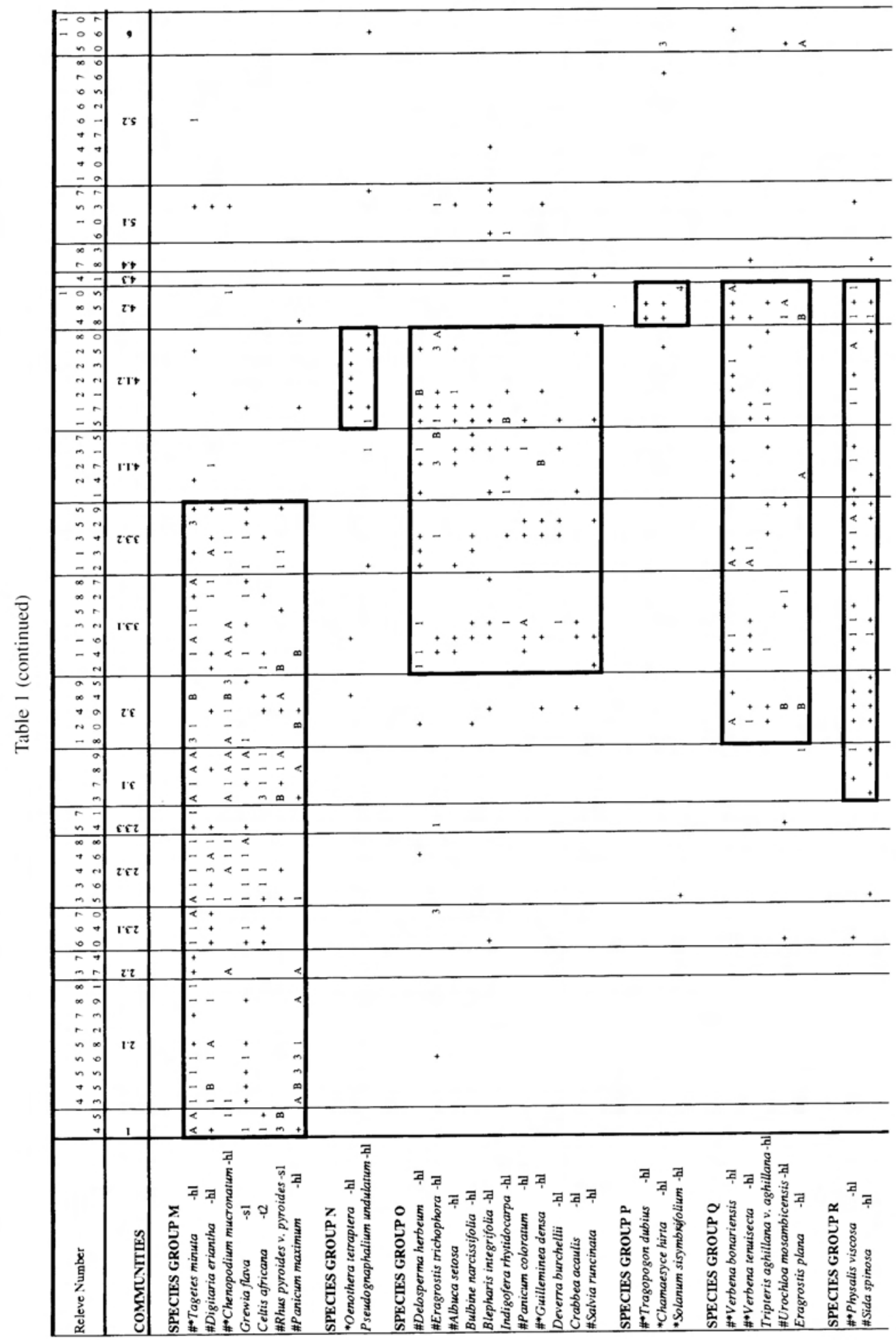




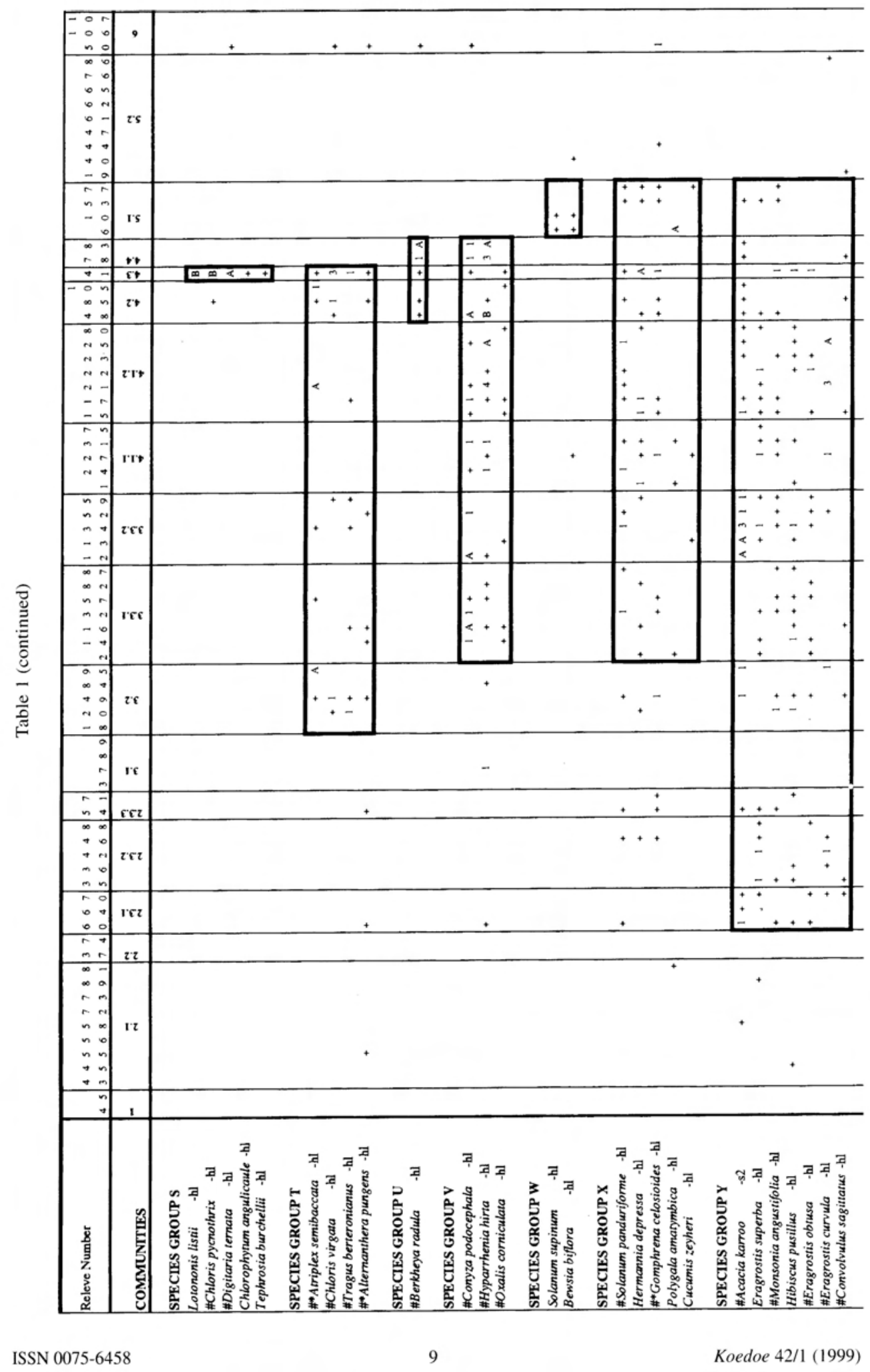




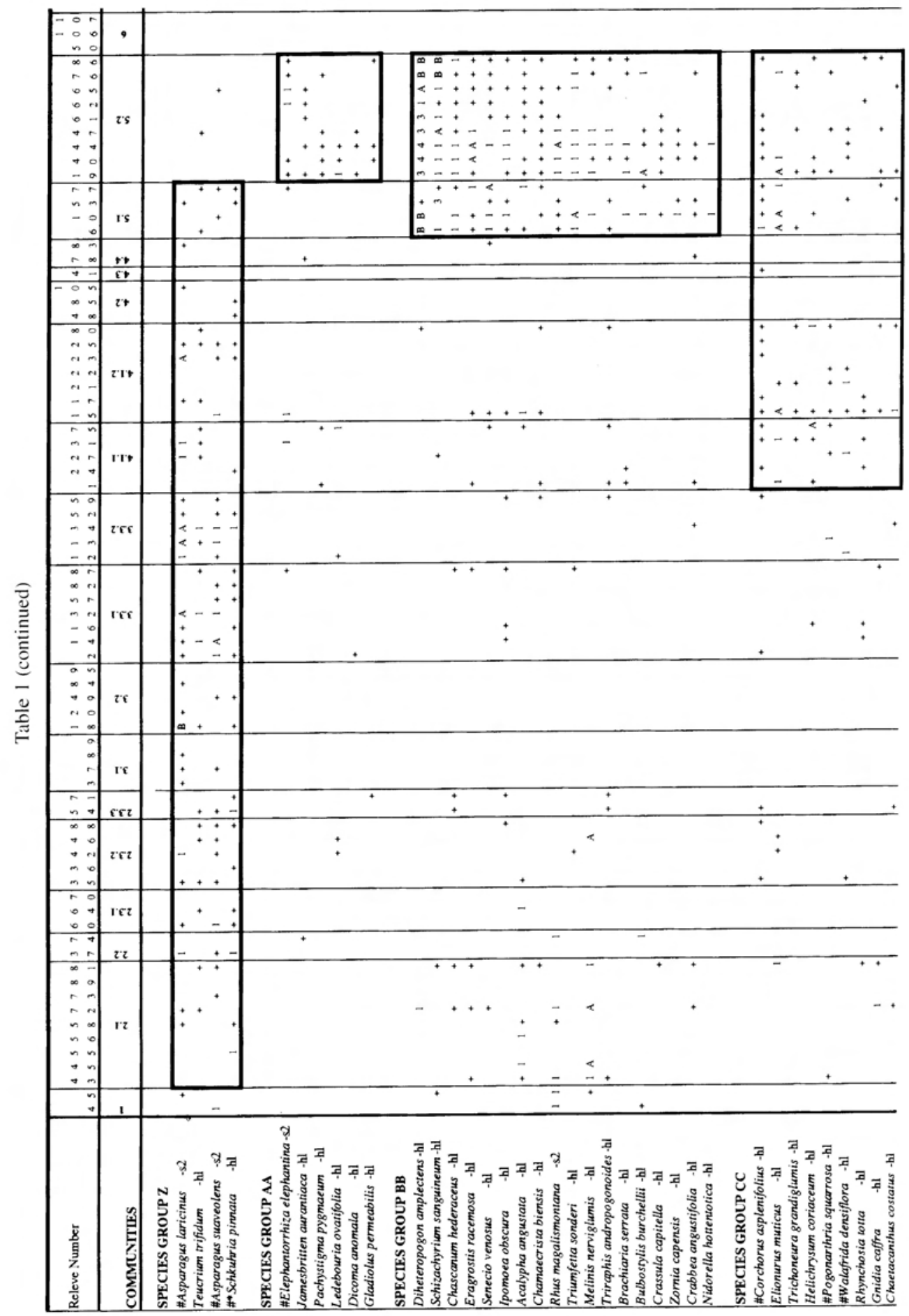




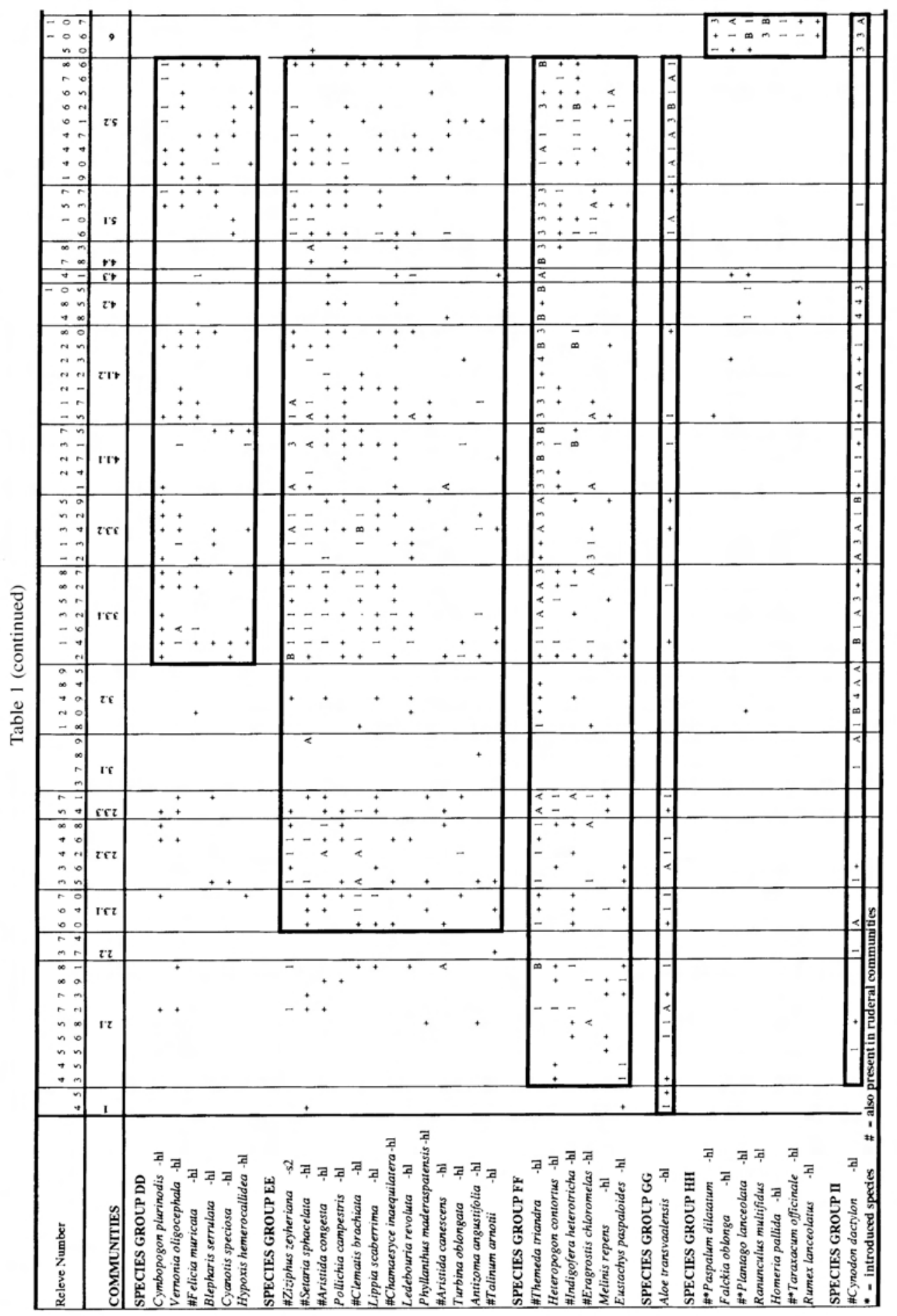




\subsubsection{Eragrostis lehmanniana Shrubby Variant}

2.3.2Acacia caffra Woody Variant

2.3.3 Themeda triandra - Acacia caffra Shrubby Variant

3. Asparagus laricinus - Acacia karroo Woodland Community
3.1. Rhus lancea - Acacia karroo Woodland Sub-community
3.2 Araujia sericifera - Acacia karroo Woodland Sub-community
3.3 Themeda triandra - Acacia karroo Woodland Sub-community

3.3.1 Acacia karroo Woody Variant

3.3.2 Grewia flava Shrubby Variant

4. Themeda triandra Grassland Community

4.1 Cynodon dactylon - Themeda triandra Grassland Sub-community

4.1.1 Themeda triandra Grassy Variant

4.1.2Acacia karroo Shrubby Variant

4.2 Tragopogon dubius - Cynodon dactylon Grassland Sub-community

4.3 Chloris virgata Grassland Sub-com munity

4.4 Berkheya radula Wetland Subcommunity

5. Schizachyrium sanguineum -

Diheteropogon amplectens

Grassland Community

\subsection{Themeda triandra Grassland Sub- community}

5.2 Diheteropogon amplectens

Grassland Sub-community

\section{Paspalum dilatatum - Cynodon dactylon Wetland Community}

\section{Description of the communities}

Many of the communities show some floristic similarity to natural communities previously described for the $\mathrm{Bc}$ land type (Bezuidenhout \& Bredenkamp 1991), Fa land type (Bezuidenhout et al. 1994b) and the $\mathrm{Fb}$ land type (Bezuidenhout et al. 1994c). There are, however, also many differences, probably due to the effect of numerous disturbances associated with urbanisation as well as the scale on which this study was done. In terms of vegetation structure, the two broad physiognomic types, namely woodland and grassland can still be distinguished. The difficulty to establish exact boundaries between plant communities, due to a mosaic distribution pattern and as a result of the intervention of man, as was recorded by Bezuidenhout \& Bredenkamp (1991), reaches its ultimate in this study. Despite the fact that it is difficult to clearly distinguish between some of the communities, their general distribution pattern on the landscape, is presented in Fig. 2.

\section{Vangueria infausta - Rhus pyroides Shrubland Community}

This shrubland community is situated on rocky outcrops (>70\% rock cover) of relatively low quartzite ridges just north of Potchefstroom in the municipal Arboretum, which is a conservation area. Although the Vangueria infausta - Rhus pyroides Shrubland Community covers small and isolated patches in the Schizachyrium sanguineum Diheteropogon amplectens Grassland Community (5) (Fig. 2), it is easily recognised and a well established, relatively undisturbed community. Most of the soil surface comprises quartzite rocks, while only about $30 \%$ of the soil surface is represented by the Glenrosa and Mispah soil forms, indicating extremely shallow soils.

The diagnostic species (species group $\mathrm{A}$, Table 1) are the indigenous forbs Pavonia burchellii, Becium angustifolium and Helichrysum setosum. These forbs form, together with the introduced therophyte, Tagetes minuta (species group M, Table 1), the indigenous fern, Pellaea callomelanos (species group D, Table 1) and the indigenous succulent Aloe transvaalensis (species group GG, Table 1) the major components of the relatively well developed herbaceous 
stratum (average canopy cover of $30 \%$ and up to $0,8 \mathrm{~m}$ tall). Although a well established grass cover is absent, grasses such as Digitaria eriantha and Panicum maximum (species group M, Table 1) do occur. The dominant species of this community are the shrubs Rhus pyroides var. pyroides (species group M, Table 1) and Vangueria infausta (species group D, Table 1). Other conspicuous woody species include the shrubs Zanthoxylum capense, Cassine burkeana and Pavetta zeyheri (species group D, Table 1) and the tree Celtis africana (species group M, Table 1). The tree stratum is poorly developed, while the shrub stratum has an average canopy cover of $60 \%$ and is up to 5 $\mathrm{m}$ tall. An average number of 20 species was recorded per sample plot of which only $6 \%$ were introduced species and therophytes.

A similar community, the Vanguerio infaustae-Acacietum caffrae was described for the Bc land type by Bezuidenhout \& Bredenkamp (1991). Although the habitats are quite similar, the lack of the trees Acacia karroo, Acacia caffra and the dominance of the shrub Rhus pyroides var. pyroides, in the Vangueria infausta - Rhus pyroides Shrubland Community currently described are the major differences between the two communities. As this community is situated close to the Fa land type, it is possible that species such as Rhus pyroides var. pyroides have encroached from the Grewio flavae-Rhoion pyroidis, described by Bezuidenhout et al. (1994b) from the dolomitic and chert grasslands of the Fa land type. Of interest is that the Vangueria infausta - Rhus pyroides Shrubland Community in the current study has only 20 species per sample plot as the other two communities mentioned have 27 and 43 species per sample plot respectively (Bezuidenhout \& Bredenkamp 1991; Bezuidenhout et al. 1994b).

\section{Rhus leptodictya - Acacia caffra Woodland Community}

The Rhus leptodictya - Acacia caffra Woodland Community covers large areas of variable habitats on hills and ridges (Fig. 2), west of Potchefstroom between the industrial area and the suburbs Ikageng, Promosa and Mohadin (Fig. 1). Large informal housing settlements are also situated in this area.

The diagnostic species of this community are those of species group F (Table 1). They include mainly indigenous species such as the trees Acacia caffra, Rhus leptodictya, Acacia robusta subsp. robusta and Euclea undulata subsp. myrtina, the herbaceous climber Pentarrhinum insipidum, the grass Brachiaria nigropedata and the forb Aerva leucura. Other species in this community include those of species groups G, L, M, Z, FF and GG (Table 1).

A similar community with respect to species composition and habitat, the Rhoo leptodictyo-Acacion caffrae (Bezuidenhout et al. 1994c) was described from the Fb land type, which has an isolated distribution to the west of the study area along the road to the city of Klerksdorp. Although encroachment of alien invaders, reported by Bezuidenhout et al. (1994c) for some associations of the Rhoo leptodictyo-Acacion caffrae, was not recorded in the current study, uncontrolled fires, the gathering of firewood and accompanying disturbances such as trampling and soil compaction are the most important threats to some of the sub-communities and variants of this community (Fig. 3).

Three sub-communities were distinguished in the Rhus leptodictya - Acacia caffra Woodland Community based upon species composition, specific topographic position on the hills and ridges and degree of disturbance (Fig. 3).

\subsection{Dombeya rotundifolia Woodland Sub- community}

The Dombeya rotundifolia Woodland Subcommunity occurs on the cooler and moister south-facing scarps, and occassionally on the crests of the hills and ridges on shallow soils of the Mispah soil form (Fig. 3). The habitat is extremely rocky with about $70 \%$ of rock on the soil surface (Fig. 2). 
This sub-community is characterised by diagnostic species such as the trees Dombeya rotundifolia, Olea europaea subsp. africana and Pappea capensis, the shrubs Grewia occidentalis, Plumbago auriculata and Boscia albitrunca and the succulent Kalanchoe thyrsiflora (species group B, Table 1). Apart from Dombeya rotundifolia which is the dominant species in some of the sample plots, two other trees, namely Acacia caffra and Acacia robusta subsp. robusta (species group F, Table 1) are co-dominant. Other woody species in this sub-community are the trees which are diagnostic for the entire community (species group F, Table 1) and the shrubs Zanthoxylum capense, Cassine burkeana (species group D, Table 1), Ehretia rigida (species group G, Table 1) and Grewia flava (species group M, Table 1). Although woody species are dominant in this sub-community, grass species such as Panicum maximum and Digitaria eriantha (species group M, Table 1), which are the dominant grass species in some areas, Eustachys paspaloides and Heteropogon contortus (species group FF, Table 1) do occur. The removal of trees for firewood was observed in this sub-community, explaining the lower average cover abundance values for woody species and subsequent higher values for herbaceous species in some of the sample plots. Disturbances to this community are further shown by the abundance of the introduced annuals Tagetes minuta (species group M) and Bidens bipinnata (species group L, Table 1) and the pioneer forb Commelina africana (species group G, Table 1). This sub-community still appears to be one of the less disturbed ones of the Rhus leptodictya - Acacia caffra Woodland Community.

The tree stratum is well developed, has an average height of $5.5 \mathrm{~m}$ and an average canopy cover of $40 \%$, The shrub and herbaceous strata are equally well developed with average canopy covers of $20 \%$ and $38 \%$ and maximum heights of $2 \mathrm{~m}$ and $1.4 \mathrm{~m}$, respectively.
An average number of 33 species was recorded per sample plot of which only $8 \%$ were introduced and $5 \%$ were therophytes.

Bezuidenhout et al. (1994c) described a similar community from the $\mathrm{Fb}$ land type, namely the Dombeyo rotundifoliae-Acacietum caffrae, an association of the Rhoo leptodictyo - Acacion caffrae.

\subsection{Vangueria infausta Woodland Sub-com- munity}

This sub-community of the Rhus leptodictya - Acacia caffra Community is associated with exposed rocks on the drier and hotter crests, and sometimes on the scarps of the hills and ridges in the study area (Fig. 2). The soil surface is rocky with the Mispah soil form the most dominant (Fig. 3).

No diagnostic species were identified for this sub-community, but it is characterised by the dominance of the shrub Vangueria infausta (species group D, Table 1) and the absence of the species of species group B (Table 1), which is diagnostic for the Dombeya rotundifolia Sub-community. The dominance of Vangueria infausta shows an affinity between this sub-community and the Vangueria infausta - Rhus pyroides Shrubland Community (1). The species of species group $\mathrm{F}$ (Table 1) which include the trees, Acacia caffra, Acacia robusta subsp. robusta and Rhus leptodictya differentiate these two communities from each other. The herbaceous stratum, which is poorly developed in comparison with the other sub-communities (average canopy cover of $20 \%$ and average height of $0.6 \mathrm{~m}$ ) includes the introduced annuals Bidens bipinnata (species group L, Table 1), Tagetes minuta and the shade-loving species, Chenopodium mucronatum (species group M, Table 1).

An average number of 21 species was recorded per sample plot of which $16 \%$ were introduced species and $11 \%$ were therophytes.

This is the only sub-community of the Rhus leptodictya - Acacia caffra Woodland 


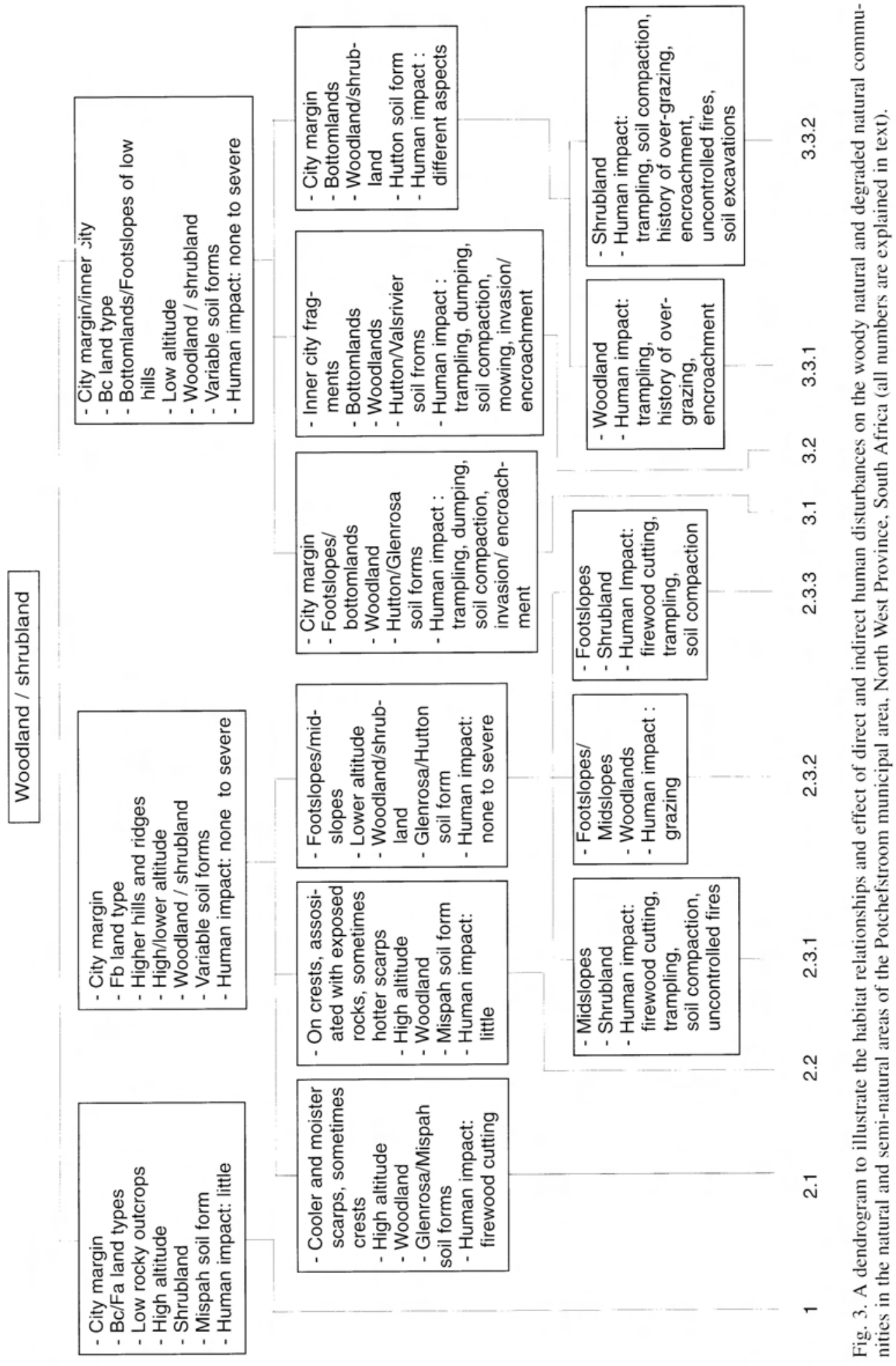


Community which is not similar to any association of the Rhoo leptodictyo - Acacion caffrae described by Bezuidenhout et al. (1994c) for the Fb land type. A similar community, the Vanguerio infaustae-Acacietum caffrae was described from the Bc land type (Bezuidenhout \& Bredenkamp 1991).

\subsection{Acacia karroo - Acacia caffra Woodland Sub-community}

The Acacia karroo - Acacia caffra Woodland Sub-community is mainly situated on the footslopes, but also on the midslopes of the hills and ridges in the study area (Fig. 2). The soils are fairly deep and consist of the Glenrosa and Hutton soil forms. Although surface rocks may be present in certain areas it is usually less than $10 \%$ of the soil surface.

No diagnostic species could be recognised for this sub-community of the Rhus leptodictya - Acacia caffra Woodland Community. It is characterised by its specific habitat and the fact that it is the only sub-community where Acacia caffra (species groups $\mathrm{E}$ and $\mathrm{F}$, Table 1) and Acacia karroo (species groups $\mathrm{K}$ and $\mathrm{Y}$, Table 1) occur together either as trees or as shrubs. The Acacia karroo Acacia caffra Woodland Sub-community can be differentiated from the other subcommunities in the community on the basis of species groups $\mathrm{Y}$ and EE (Table 1) which include the shrubs Acacia karroo and Ziziphus zeyheriana, the climber Clematis brachiata, the grasses Eragrostis superba, Eragrostis curvula, Eragrostis chloromelas and Aristida canescens and the forbs Hibiscus pusillus, Lippia scaberrima and Chamaesyce inaequilatera. Other species in this sub-community are those which are mentioned as diagnostic (species group $\mathrm{F}$, Table 1) or present (species groups G, L, M, Y, Z, EE, FF, GG and II, Table 1) in the community. Those species include the introduced therophyte Tagetes minuta and the indigenous succulent Aloe transvaalensis.

A similar community, the Acacietum karroocaffrae, an association of the Rhoo leptodictyo-Acacion caffrae, was described from the
Fb land type (Bezuidenhout et al. 1994c). The two sub-associations which were distinguished by Bezuidenhout et al. (1994c) on the basis of the gradient of the slopes and the soil depth were not recognised in this community. The apparent absence of the two sub-associations could be the result of human influences in this community which varies from trampling to ringbarking and cutting of trees for firewood. Species such as the tall shrub Rhus pyroides and the tree Ziziphus mucronata subsp. mucronata, which were described by Bezuidenhout $e t$ al. (1994c) as important components of the Acacietum karroo-caffrae were hardly ever noticed in the Acacia karroo - Acacia caffra Woodland/Shrubland Sub-community.

Three variants could be distinguished in this sub-community based upon terrain type, vegetation structure and intensity of disturbances (Fig. 3).

\subsubsection{Eragrostis lehmanniana Shrubby Variant}

This variant represents disturbed areas of the Acacia karroo - Acacia caffra Woodland Sub-community and more specific on the midslopes of the hills and ridges. No diagnostic species were identified, but this shrubby variant is differentiated from the other variants by the presence of only shrub forms of Acacia karroo (species group Y, Table 1). These shrubs are in many cases coppice growth from trunks which have been cut down on ground level, for firewood. The dominant species in this variant is Acacia caffra (species group F, Table 1). The presence of the species of species group D (Table $1)$ indicates an affinity with the sub-communities (2.1 and 2.2) in the more rocky areas, and include the shrubs Zanthoxylum capense and Cassine burkeana. The soil is compacted due to water runoff and trampling by wood gatherers and this probably resulted in the establishment of the grass species Eragrostis lehmanniana (species group L, Table 1).

The tree (average canopy cover of $38 \%$ and average height of $5 \mathrm{~m}$ ), shrub (average 
canopy cover of $23 \%$ and average height of $1.8 \mathrm{~m}$ ) and herbaceous strata (average canopy cover of $45 \%$ and average height of $1 \mathrm{~m}$ ) are all well developed. An average of 36 species was recorded per sample plot of which only $8 \%$ were introduced and $8 \%$ were therophytes.

\subsubsection{Acacia caffra Woody Variant}

This is the typical and also the least disturbed variant of the Acacia karroo - Acacia caffra Woodland Sub-community of the Rhus leptodictya - Acacia caffra Woodland Community. No diagnostic species occur in this woody variant. It can be differentiated from the other variants by the presence of tree forms of Acacia karroo (species group $\mathrm{K}$, Table 1) which is co-dominant with the tree Acacia caffra (species group F, Table 1), the shade-loving introduced forb Chenopodium mucronatum and the indigenous shrub Grewia flava (species group M, Table 1). Other species are those which are discussed for the sub-community. The tree stratum with an average canopy cover of 55 $\%$ and average height of $5 \mathrm{~m}$ is well developed in comparison with the shrub stratum (average canopy cover of $15 \%$ and average height of $1.5 \mathrm{~m}$ ). The herbaceous stratum is also well developed with an average canopy cover of $40 \%$ and an average height of $0.8 \mathrm{~m}$. An average number of 36 species was recorded per sample plot of which only $12 \%$ were introduced and $11 \%$ were therophytes.

\subsubsection{Themeda triandra Shrubby Variant}

The Themeda triandra Shrubby Variant probably represents a disturbed version of the Acacia karroo - Acacia caffra Woodland Sub-community, but is mainly situated in small patches on the footslopes of the hills and ridges. It is characterised by shrub forms of the dominant tree of the entire community, Acacia caffra (species group E, Table 1). The tree stratum is largely removed or being cut down and left to dry for firewood, and only isolated individuals of Acacia caffra and Rhus leptodictya (species group F, Table 1) remain. The shrub stratum is relatively well developed with an average canopy cover of $30 \%$ and average height of $2.2 \mathrm{~m}$.
The herbaceous stratum which consists mainly of the grasses Themeda triandra, Heteropogon contortus (species group FF, Table 1) and Aristida congesta (species group EE, table 1) is relatively well developed (average canopy cover of $25 \%$ and average height of $0.8 \mathrm{~m}$ ). An average number of 35 species was recorded per sample plot of which $9 \%$ were introduced and $9 \%$ were therophytes.

\section{Asparagus laricinus - Acacia karroo Woodland Community}

The Asparagus laricinus - Acacia karroo Woodland Community covers large areas on the city margin and also in fragmented natural areas inside the city (Figures 2 and 3 ). On the city margin it is mainly situated in bottomland areas and along the footslopes of quartzite hills and ridges (Fig. 2), north and north-west of Potchefstroom. The soil is usually relatively deep with variable clay contents and no or little surface rocks.

No diagnostic species were identified for this community, but it is characterised by the presence of the dominant species Acacia karroo (species groups $\mathrm{K}$ and Y, Table 1) as trees or as shrubs. In the other community in the study area where Acacia karroo was found, namely the Acacia karroo - Acacia caffra Woodland Sub-community (2.3), it usually occurs together with the tree Acacia caffra. The Asparagus laricinus - Acacia karroo Woodland Community is further characterised by the absence of the species of species groups $\mathrm{F}$ and $\mathrm{G}$ (Table 1). The only other woody species in this community are the tree Celtis africana (species group M, Table 1) and the shrubs Grewia flava, Rhus pyroides var. pyroides (species group $\mathrm{M}$, Table 1), Asparagus laricinus and Asparagus suaveolens (species group Z, Table 1). The herbaceous species include forbs such as the introduced therophytes Bidens bipinnata (species group L, Table 1), Tagetes minuta, Chenopodium mucronatum (species group M, Table 1) and Schkuhria pinnata (species group Z, Table 1) and indigenous species typical for the Grassveld Biome in the western Transvaal, such as Hibiscus pusillus (species group $\mathrm{Y}$, table 1), Teucrium trifidum 


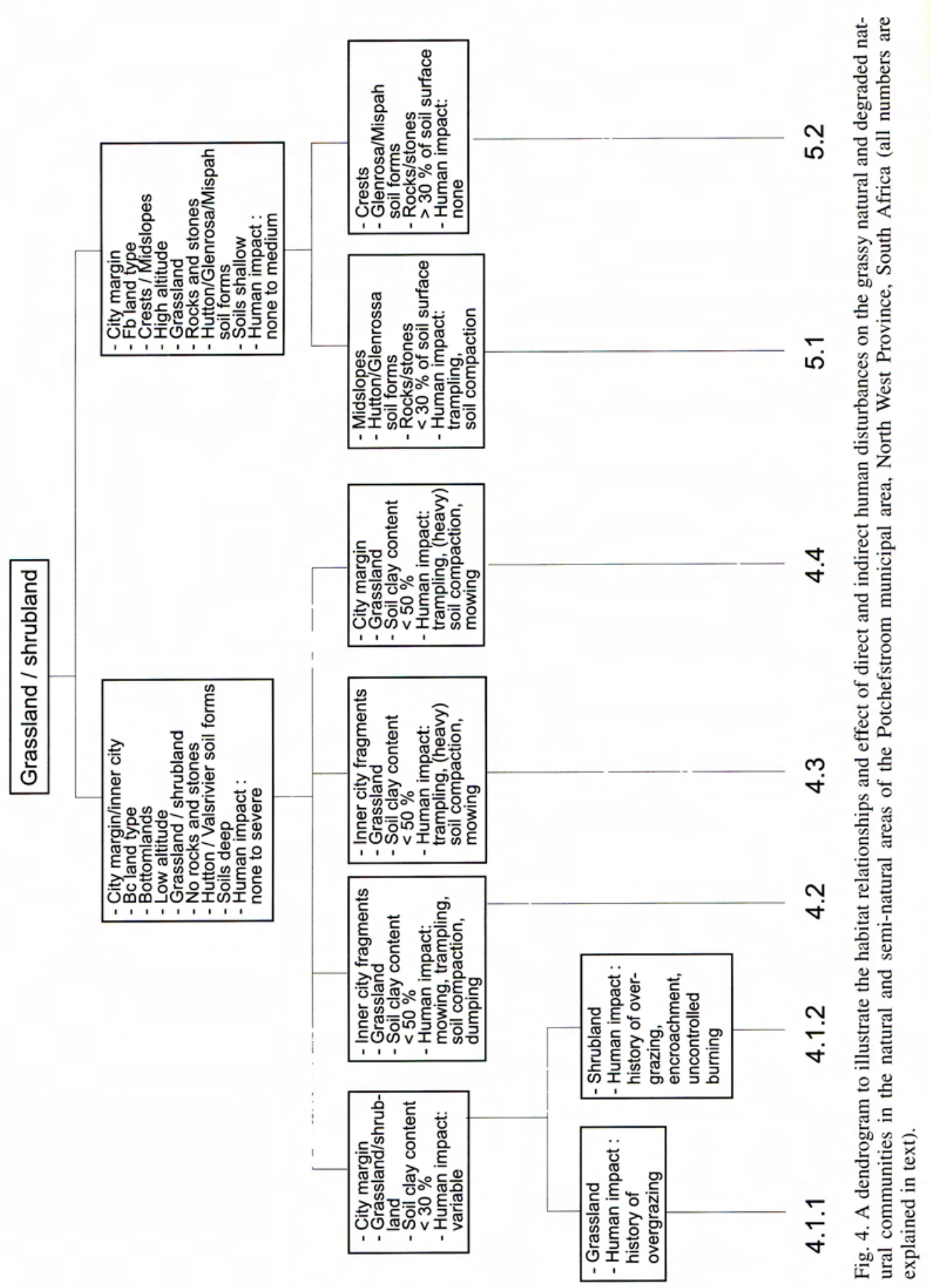


(species group Z, Table 1) and Lippia scaberrima (species group EE, Table 1). Other herbaceous species are the climber Clematis brachiata and the geophyte Ledebouria revoluta (species group $\mathrm{EE}$, Table 1). Although rarely dominant, indigenous grasses such as Digitaria eriantha (species group M, Table 1), Themeda triandra, Heteropgon contortus (species group FF, Table 1), Setaria sphacelata (species group EE, Table 1) and the cosmopolitan invader Cynodon dactylon (species group II, table 1) were also recorded.

A similar community, the Acacion karroo, was described by Bezuidenhout \& Bredenkamp (1991) for the footslopes and bottomland flats of the $\mathrm{Bc}$ land type. The different associations and sub-associations described for this alliance on the basis of ecological characteristics (Bezuidenhout \& Bredenkamp 1991) were not clearly distinguished in the current study, probably due to direct or indirect human disturbances. Bredenkamp et al. (1989) also mentioned that the encroachment of Acacia karroo into areas not previously occupied by woody vegetation, hampers the habitat interpretation of Acacia karroo communities in the Grassland Biome.

Three different sub-communities were identified in the Asparagus laricinus - Acacia karroo Woodland Community currently described, mainly based upon various direct and indirect human influences (Fig. 3). Species groups Q, R, T, U, X and DD (Table 1) indicate an affinity between some of the sub-communities of this community and the grassland communities. This could be an indication that the entire Asparagus laricinus - Acacia karroo Woodland Community originated as a result of encroachment of woody species into grasslands. If this is true, Acacia karroo should be regarded as an apophyte and certain sub-communities and variants of this community will rather represent degraded encroached or ruderal communities, as was suggested by Cilliers \& Bredenkamp (in press a) for small vacant lots inside Potchefstroom. The Asparagus laricinus Acacia karroo Woodland Community as well as other woody communities described in this study (1. Vangueria infausta - Rhus pyroides Shrubland Community; and, 2. Rhus leptodictya - Acacia caffra Woodland Community) can be differentiated from the typical grassland communities on the basis of the presence of species groups $\mathrm{K}, \mathrm{L}$ and $\mathrm{M}$ (Table 1). The fact that Acacia karroo Woodlands are in competition with grasslands were also discussed by researchers such as Louw (1951), Friedel (1987) and Bredenkamp et al. (1989) amongst others. This Asparagus laricinus - Acacia karroo Woodland Community with its sub-communities are probably new syntaxa, representing degraded phases of the Acacion karroo (Bezuidenhout \& Bredenkamp 1991) specifically associated with areas in and around urban environments in the Grassland Biome.

The following sub-communities were distinguished in the Asparagus laricinus - Acacia karroo Woodland Community currently described:

\subsection{Rhus lancea-Acacia karroo Woodland Sub-community}

This well-established woodland is situated only on the city margin in the Arboretum, which is a conservation area in the northern part of the Potchefstroom Municipal Area. It occurs at the footslopes of a low hill, as well as on the adjacent bottomland area on rocky but also on deeper sandy soils of the Glenrosa and Hutton soil forms (Fig. 2). This sub-community seems to encroach into other parts of the Asparagus laricinus Acacia karroo Woodland Community and the Schizachyrium sanguineum Diheteropogon amplectens Grassland Community (5.) in the study area (Fig. 2).

The species of species group $\mathrm{H}$ (Table 1) are the diagnostic species and include tree species such as the indigenous Rhus lancea, which is co-dominant with Acacia karroo (species group K, Table 1) and the introduced Robinia pseudoacacia. Shrub species which are diagnostic are indigenous species such as Maytenus heterophylla and Acacia hebeclada subsp. hebeclada and the introduced species Pyracantha angustifolia. Other species which were recorded only once are the declared invader Opuntia imbricata, the introduced tree Ligustrum lucidum 
and the indigenous shrub Rhus rigida (Cilliers 1998). The tree stratum is well developed (average canopy cover of $70 \%$ and up to $6 \mathrm{~m}$ tall) while the shrub stratum has an average canopy cover of $18 \%$ and an average height of $1.4 \mathrm{~m}$. The herbaceous stratum is also well developed (average canopy cover of $50 \%$ ) and it often forms two layers with Chenopodium mucronatum the dominant species in the lower layer (average height of $0.3 \mathrm{~m}$ ) and Tagetes minuta the dominant species in the higher layer (average height of $1.4 \mathrm{~m}$ ). No sign of cutting and gathering of wood were observed in this sub-community, but the establishment of introduced annuals underneath the trees is the result of human disturbances such as trampling and the unauthorised dumping of garden refuse. An average number of 19 species was recorded per sample plot of which $30 \%$ were introduced and $15 \%$ were therophytes.

Bezuidenhout \& Bredenkamp (1991) mentioned that the presence of Rhus lancea in one of the syntaxa of the Acacion karroo indicates the presence of lime in the soil, but this was only recorded in the western, drier parts of the Bc land type. As this community currently described does not fit any of these characteristics, it probably established due to encroachment of Rhus lancea into the footslopes and bottomlands of hills and ridges occupied by the Asparagus laricinus Acacia karroo Woodland Community in the Bc land type. As was mentioned earlier the Arboretum is situated close to the Fa land type and the source of Rhus lancea encroachment could be the Rhoo lanceaeAcacion eriolobae, described for the slightly undulating bottomlands of the Fa land type by Bezuidenhout et al. (1994b). It is more likely that this sub-community developed due to encroachment of Rhus lancea from adjacent gardens which were established some 50 years ago at the top of the hill around a water purification plant. The occurrence of other garden escapes such as Ligustrum lucidum, Pyracantha angustifolia and Robinia pseudoacacia may prove this assumption to be the correct one.
Araujia sericifera - Acacia karroo Woodland Sub-community

The Araujia sericifera - Acacia karroo Woodland Sub-community forms patches on large fragmented natural areas inside the city where human disturbances such as trampling, dumping of garden refuse and mowing at least every 8-10 weeks occur (Fig. 3). It is situated in flat bottomland plains on deep soils with a relatively high clay content of the Hutton and Valsrivier soil forms (Fig. 2).

The tree stratum which consists mainly of the dominant species Acacia karroo (species group $\mathrm{K}$, Table 1) is on average $4.8 \mathrm{~m}$ tall and has an average canopy cover of $35 \%$. The shrub stratum is on average $1.5 \mathrm{~m}$ tall and has an average canopy cover of $10 \%$, while the herbaceous layer has an average canopy cover of $45 \%$ and an average height of $0.7 \mathrm{~m}$. The only diagnostic species in this sub-community is the invasive alien climber Araujia sericifera and another climber which is probably indigenous, Galium spurium (species group I, Table 1). Although not very strong, the presence of the species of species group $\mathrm{J}$ (Table 1) indicates an affinity between this sub-community and the Rhus lancea - Acacia karroo Woodland Sub-community (3.1), which has also established due to long-term anthropogenic influences. These species include the forbs Malvastrum coromandelianum and Commelina benghalensis, the turf grass Pennisetum clandestinum, the indigenous annual grass, Setaria verticillata and the exotic tree Melia azedarch which is regarded as a dangerous declared invader (Henderson 1995). The Araujia sericifera - Acacia karroo Woodland Sub-community is further characterised by the absence of species of species groups $\mathrm{O}$, $\mathrm{V}$ and $\mathrm{X}$ and the low cover of species of species groups Y, EE, FF and GG (Table 1), which are mainly indigenous species, quite common to grasslands and woodlands in the Grassland Biome, according to Bezuidenhout \& Bredenkamp (1991) and Bezuidenhout et al. (1994 a, b, c). An average of 25 species was recorded per sample plot of which $28 \%$ were introduced and $16 \%$ were therophytes.

This sub-community of the Asparagus laricinus - Acacia karroo Woodland Community 
forms patches of woodland inside grasslands such as the Tragopogon dubius - Cynodon dactylon Grassland Sub-community (4.2). The area occupied by this woodland in the inner city, could be much larger if the young Acacia karroo plants which have tried to establish inside the grassland area were not frequently cut down. A similar community, the Asparagus laricinus - Acacia karroo Araujia sericifera Sub-community of the Asparagus laricinus - Acacia karroo Community was described by Cilliers \& Bredenkamp (1998) as a community which encroached from fragmented natural areas into disturbed areas along railway lines.

\subsection{Themeda triandra - Acacia karroo Woodland Sub-community}

This sub-community is situated on the bottomland plains on the city margin north and north-west of Potchefstroom (Fig. 2).

Although no diagnostic species occur in this sub-community it is characterised by the high cover of the dominant species Acacia karroo which may occur as a tree (species group $\mathrm{K}$, Table 1) or as a shrub (species group Y, Table 1) together with the dominant grass species Themeda triandra (species group FF, Table 1). The Themeda triandra Acacia karroo Woodland Sub-community is differentiated from the other sub-communities in the Asparagus laricinus - Acacia karroo Woodland Community by the presence of the species of species groups $\mathrm{O}, \mathrm{V}, \mathrm{X}$ and DD (Table 1). These species include typical grassland species such as the indigenous forbs Delosperma herbeum, Blepharis integrifolia, Crabbea acaulis, Hermannia depressa and Vernonia oligocephala. Other species in these species groups indicate according to Cilliers (1998); Cilliers \& Bredenkamp (1998); Cilliers \& Bredenkamp (in press a, b) and Cilliers et al. (1998) the degraded nature of this sub-community. These species include the introduced forbs Guilleminea densa, Atriplex semibaccata, Alternanthera pungens and Gomphrena celosioides and the indigenous grasses Eragrostis trichophora, Urochloa mosambi- censis, Chloris virgata and Tragus berteronianus. Other species in this sub-community are the shrubs Asparagus laricinus, Asparagus suaveolens (species group Z, Table 1) and Ziziphus zeyheriana (species group EE, Table 1).

The Themeda triandra - Acacia karroo Woodland Sub-community is probably a lower syntaxon of the Acacion karroo, an alliance described for the $\mathrm{Bc}$ land type (Bezuidenhout \& Bredenkamp 1991).

Two variants were distinguished in this subcommunity based upon vegetation structure and degree of disturbance (Fig. 3).

\subsubsection{Acacia karroo Woody Variant}

This typical variant of the Themeda triandra - Acacia karroo Woodland Sub-community is the less disturbed variant and has a well established tree stratum with an average height of $5 \mathrm{~m}$ and an average canopy cover of $40 \%$. The trees include the dominant species, Acacia karroo (species group K, Table 1), Celtis africana (species group M, table 1) and a species which were only recorded once, Acacia hereroensis (Cilliers 1998). The shrub and herbaceous strata consist of the species mentioned earlier in the description of the sub-community and although it is relatively well developed, it is always subordinate to the tree stratum. An average number of 38 species was recorded per sample plot of which $17 \%$ were introduced and $10 \%$ were therophytes.

\subsubsection{Grewia flava Shrubby Variant}

The Grewia flava Shrubby Variant represents a severely disturbed variant of the Themeda triandra - Acacia karroo Woodland Sub-community. Disturbances include uncontrolled burning, heavy trampling and even soil excavations (Fig. 3). No diagnostic species were identified for this variant but structurally it can be differentiated from the other variant by the poorly developed tree stratum (average canopy cover of less than $5 \%$ and up to $3.8 \mathrm{~m}$ tall). This shrubby variant is further characterised 
by the presence of a well developed shrub stratum which is on average $1.4 \mathrm{~m}$ tall and has an average canopy cover of $40 \%$ and include Acacia karroo (species group Y, Table 1), Grewia flava, Rhus pyroides var. pyroides (species group M, table 1), Asparagus laricinus and Asparagus suaveolens (species group Z, Table 1). The herbaceous stratum has an average height of $0.8 \mathrm{~m}$ and an average canopy cover of $35 \%$. An average number of 37 species was recorded of which $16 \%$ were introduced and $12 \%$ were therophytes.

\section{Themeda triandra Grassland Community}

The Themeda triandra Grassland Community is situated in lower-lying areas in a variety of habitats on the city margin and also on fragmented natural areas inside the city (Figures 2 and 4 ). The soils are relatively deep with a high clay content ( $>40 \%$ ) and belong to the Hutton or Valsrivier soil forms. No surface rocks are visible in most of the areas occupied by this community. This community tends to form mosaics with the Asparagus laricinus - Acacia karroo Woodland Community (3), and may also be encroached by certain species of this community (Fig. 2).

No diagnostic species were identified for this community, but it is characterised, however, by the species of species group V (Table 1) and the absence of the species of species groups K, L and M (Table 1). The dominant species is mainly the indigenous grass Themeda triandra (species group FF, Table 1) but it may be subordinate to other species in some of the more disturbed sub-communities of this community. Species of species groups X, Y, Z and EE (Table 1) are those which this Themeda triandra Grassland Community share with the woodland (1, 2 and 3) and rocky grassland (5.1 and 5.2) communities. Species which are common in most of the communities in the study area are those of species groups FF, GG and II (Table 1) and include the highly invasive cosmopolitan grass Cynodon dactylon.
Four sub-communities are recognised in this community based upon the type, degree and history of disturbance, but also on the clay content of the soil (Fig. 4). A similar community, the Themedo triandrae-Heteropogonetum contorti, an association of the Heteropogonion contorti was described by Bezuidenhout \& Bredenkamp (1991) for the Bc land type. Three (4.1, 4.2 and 4.3) of the four sub-communities of the Themeda triandra Grassland Community could possibly be regarded as new sub-associations for the Themedo triandrae-Heteropogonetum contorti (Bezuidenhout \& Bredenkamp 1991). The syntaxonomic position of the fourth subcommunity is not clear but is placed in the Themeda triandra Grassland Community in the present study, despite the absence of species from species groups X, Y, Z, CC and DD (Table 1).

\subsection{Cynodon dactylon - Themeda trian- dra Grassland Sub-community}

This sub-community is situated on the city margin in bottomland plains on deep soils with a clay content of $<30 \%$ (Figs $2 \& 4$ ).

The grass species Themeda triandra (species group FF, Table 1) is dominant. The high cover of the invasive grass species Cynodon dactylon (species group II, Table 1), howev$\mathrm{er}$, is an indication of degraded conditions, as was observed in the Potchefstroom wetlands by Cilliers et al. (1998). No diagnostic species were identified for the Cynodon dactylon - Themeda triandra Grassland Subcommunity, but it can be distinguished from the other sub-communities because of the presence of the species of species group $\mathrm{O}$ (Table 1). These species include the indigenous forbs Delosperma herbeum, Blepharis integrifolia and Indigofera rhytidocarpa, the geophytes Albuca setosa and Bulbine narcissifolia and the grasses Eragrostis trichopho$\mathrm{ra}$ and Panicum coloratum. Other species are those which are mentioned in the discussion of the Themeda triandra Grassland Community which include the grasses Hyparrhenia hirta (species group V, Table 1), Eragrostis superba (species group Y, 
Table 1), Pogonarthria squarrosa (species group CC, Table 1), Setaria sphacelata (species group EE, Table 1) and Heteropogon contortus (species group FF, Table 1).

Two variants which differ with respect to vegetation structure and intensity of past disturbances (Fig. 4) were recognised in this sub-community.

\subsubsection{Themeda triandra Grassy variant}

This is the typical grassland variant of the Cynodon dactylon - Themeda triandra Grassland Sub-community and is very similar to the Themedo triandraeHeteropogonetum contorti (Bezuidenhout \& Bredenkamp, 1991), except for the prominence of the invasive grass species Cynodon dactylon (species group II, Table 1). The herbaceous stratum is well developed, $0.8 \mathrm{~m}$ tall on average and has an average canopy cover of $60 \%$. No tree layer exists, while the shrub layer is either absent or poorly developed. An average number of 30 species was recorded per sample plot of which only $11 \%$ were introduced and only $6 \%$ were therophytes.

\subsubsection{Acacia karroo Shrubby Variant}

The diagnostic species of the Acacia karroo Shrubby Variant are the forbs Oenothera tetraptera and Pseudognaphalium undulatum (species group N, Table 1). This variant is, however, better characterised by the encroachment of shrubs such as Acacia karroo (species group Y, Table 1) Asparagus laricinus and Asparagus suaveolens (species group Z, Table 1) into the Cynodon dactylon - Themeda triandra Grassland Sub-community. It represents, therefore, a much degraded state of the Cynodon dactylon - Themeda triandra Grassland Sub-community. The degradation is probably the result of a history of overgrazing, uncontrolled burning and other bad management practises. The shrub stratum has an average height of $1.3 \mathrm{~m}$ and an average canopy cover of $15 \%$, while the herbaceous stratum has an average canopy cover of $40 \%$ and is $0.8 \mathrm{~m}$ tall on average.
An average number of 37 species was recorded per sample plot of which $12 \%$ were introduced and $7 \%$ were therophytes.

Although this shrubby variant is structurally very similar to the Grewia flava Shrubby Variant (3.3.2) of the Themeda triandra Acacia karroo Woodland Community (3.3) described in the current study, it can be distinguished from each other on the basis of species groups L and M (Table 1).

\subsection{Tragopogon dubius - Cynodon dacty- lon Grassland Sub-community}

This sub-community is situated inside the city on fragmented natural areas and forms mosaics with the Araujia sericifera - Acacia karroo Woodland Sub-community of the Asparagus laricinus - Acacia karroo Woodland Community (Fig. 2). Human influences such as trampling, dumping of garden refuse and frequent mowing does have an effect on the species composition (Fig. 4). This sub-community can also be regarded as a further degraded state of the Cynodon dactylon - Themeda triandra Grassland Sub-community (4.1) of the Themeda triandra Grassland Community (4), but specifically due to long term human influences in an urban context, especially frequent mowing.

Although the dominant species for the entire Themeda triandra Grassland Community (4), Themeda triandra (species group FF, Table 1) still has a high cover, it is subordinate to the highly invasive stoloniferous and rhizomatous grass Cynodon dactylon (species group II, Table 1). The invasion by Cynodon dactylon is the direct result of trampling and frequent mowing of these areas. The diagnostic species (species group $\mathrm{P}$, Table 1) are typical ruderal species such as the introduced forbs Tragopogon dubius and Chamaesyce hirta, which were also recorded on vacant lots (Cilliers \& Bredenkamp in press a) and intensively managed sites (Cilliers \& Bredenkamp in press b) and the declared invader Solanum sisymbrifolium (Wells et al. 1986; Henderson 1995). This sub-community can be distinguished from 
the Cynodon dactylon - Themeda triandra Grassland Sub-community (4.1) as well as from the woodland communities (1,2 and 3) on the absence or very low cover abundance values of the species of species groups $\mathrm{O}$, CC, DD, EE, FF and GG (Table 1). Other species in this sub-community include the introduced forbs Verbena bonariensis (species group Q, Table 1) and Physalis viscosa (species group R, Table 1). Although encroachment of Acacia karroo (species group Y, Table 1) does take place, it is controlled by frequent mowing. If mowing is stopped it is possible that the adjacent Araujia sericifera - Acacia karroo Woodland Sub-community (3.2) will totally replace the Tragopogon dubius - Cynodon dactylon Grassland Sub-community in future.

The tree stratum is absent while the poorly developed shrub stratum is $0.3 \mathrm{~m}$ tall on average and has an average canopy cover of only $3 \%$. The herbaceous stratum, however, has an average height of $0.5 \mathrm{~m}$ and an average canopy cover of $50 \%$. An average number of 23 species was recorded per sample plot of which $36 \%$ were introduced and $14 \%$ were therophytes. The fact that $73 \%$ of all species in this sub-community (Table 1) were also encountered in ruderal communities of the study area (Cilliers 1998), further indicates the great effect of anthropogenic influences in this sub-community.

\subsection{Chloris virgata Grassland Sub-com- munity}

The Chloris virgata Grassland Sub-community is represented by a single sample plot on a large fragmented natural site in a residential area which is heavily trampled. A part of this fragmented grassland, in which a children's playground was established, was included in the study of intensively managed sites (Cilliers \& Bredenkamp in press b). The entire area probably fits better in the study of intensively managed sites in Potchefstroom (Cilliers \& Bredenkamp in press $\mathrm{b}$ ), but parts of it was excluded from that study because mowing does not take place every 2-3 weeks as in the other parks but every 8 - 10 weeks like in other fragmented natural areas in this study (Labuschagne pers. comm.). This sub-community can also be regarded as a degraded form of the Cynodon dactylon - Themeda triandra Grassland Sub-community, but it is in this case more the result of heavy trampling than of frequent mowing.

The herbaceous stratum which consists mainly of grass species is $0.6 \mathrm{~m}$ tall on average and has an average canopy cover of 60 $\%$, while tree and shrub strata are absent. The indigenous pioneer grass species Chloris virgata (species group T, Table 1) is the dominant species. The diagnostic species are those of species group S (Table 1) which include other pioneer grass species Chloris pycnothrix and Digitaria ternata and remnants from the natural grasslands, namely the forbs Lotononis listii and Tephrosia burchellii and the geophyte Chlorophytum angulicaule, which seem to withstand the high mowing and trampling intensities in this area. Other species in this sub-community include the pioneer grass species Tragus berteronianus (species group T, Table 1), the indigenous forbs Hermannia depressa (species group X, Table 1), Monsonia angustifolia and Hibiscus pusillus (species group $\mathrm{Y}$, Table 1) and other indigenous grasses such as Eragrostis obtusa (species group Y, table 1) and Themeda triandra (species group FF, Table 1). 32 species were recorded in the sample plot which represents this community of which only 4 species were introduced and 5 species were therophytes.

A number of similar, so-called trampled communities were described in Potchefstroom on vacant lots (Cilliers \& Bredenkamp in press a), on intensively managed sites (Cilliers \& Bredenkamp in press b) and along roadside verges (Cilliers 1998).

\subsection{Berkheya radula Wetland Sub-com- munity}

This sub-community is situated in a seasonally wet bottomland area inside the Themeda triandra Grassland on the city margin, on 
very clayey soils (> $50 \%$ clay) of the Valsrivier soil form (Fig. 2).

No diagnostic species were identified in this sub-community, but it is characterised by its specific habitat and the dominance of the grass species Themeda triandra (species group FF, Table 1) together with the indigenous forb Berkheya radula (species group $\mathrm{U}$, Table 1). The presence of Berkheya radula suggests an affinity with the two degraded sub-communities (4.2 and 4.3) which may be the result of high clay contents in the soil. Other species in this sub-community include the grasses Hyparrhenia hirta (species group V, Table 1) and Setaria sphacelata (species group EE, Table 1) and the forbs Conyza podocephala (species group V, Table 1) and Pollichia campestris (species group EE, Table 1).

The Berkheya radula Wetland Sub-community is not much disturbed, except for encroachment by the shrub Acacia karroo (species group Y, table 1) probably due to a history of overgrazing. The herbaceous stratum is well developed with an average canopy cover of $50 \%$ and an average height of $1.0 \mathrm{~m}$, while the shrub stratum is poorly developed and the tree stratum is absent. An average number of 20 species was recorded per sample plot of which only $5 \%$ were introduced and $5 \%$ were therophytes.

A similar grassland community was described for the wetland areas along the Mooi River in the municipal area of Potchefstroom (Cilliers et al. 1998).

\section{Schizachyrium sanguineum - Diheteropogon amplectens Grassland Community}

The Schizachyrium sanguineum - Diheteropogon amplectens Grassland Community is situated on the higher-lying crests and midslopes of hills and ridges on the city margin (Fig. 2). The soil is relatively shallow, and belongs to the Mispah, Glenrosa or Hutton soil forms. The soil surface is rocky and have isolated quartzite outcrops (Fig. 4).
The species of species group BB (Table 1) which are all indigenous, are the diagnostic species. These species include the grasses Diheteropogon amplectens and Schizachyrium sanguineum, which are indicators of shallow rocky soils (Bezuidenhout et al. 1994d), Eragrostis racemosa, Melinis nerviglumis, Brachiaria serrata and Triraphis andropogonoides. Other diagnostic species are the forbs Senecio venosus, Plexipus hederaceus, Ipomoea obscura, Acalypha angustata, Chamaecrista biensis, Triumfetta sonderi, Bulbostylis burchellii, Zornia capensis, Crassula capitella and Crabbea angustifolia and the dwarf-shrub Rhus magalismontana. Other species in this community are shared with the other grassland communities and woodland communities in this study, namely the species of species groups CC, DD and EE (Table 1). Some of the more common species include the grasses Themeda triandra and Heteropogon contortus, the forbs Indigofera heterotricha (species group FF, Table 1) and Pollichia campestris (species group EE, Table 1) and the succulent Aloe transvaalensis (species group GG, Table 1). Probably indicative of the relatively undisturbed condition of this community is the absence of the invasive grass Cynodon dactylon (species group II, Table 1).

Similar communities namely, the Diheteropogono amplectentis-Schizachyrion sanguinei from the $\mathrm{Fb}$ land type (Bezuidenhout et al. 1994c) and the Schizachyrium sanguineum - Diheteropogon amplectens Major Grassland from the Bankenveld grasslands in the Lichtenburg area (Bezuidenhout et al. 1994d) were previously described.

Two sub-communities could be recognised in the Schizachyrium sanguineum Diheteropogon amplectens Grassland Community currently described, based upon terrain types, soil forms and rockiness of soil surface (Fig. 4).

\subsection{Themeda triandra Grassland Sub- community}

The Themeda triandra Grassland Sub-community is situated along the midslopes on deeper soils of the Hutton and Glenrosa soil 
forms (Fig. 2). These areas are more liable to human influences such as trampling than the other sub-community (5.2) which is situated on the crests.

The diagnostic species for this sub-community is the forb Solanum supinum and the grass Bewsia biflora (species group W, Table 1 ), but it is better characterised by the dominance of the grass species Themeda triandra (species group FF, Table 1) and the absence of species group AA (Table 1). The presence of the forbs Solanum panduriforme, Gomphrena celosioides (species group X, Table 1) and Schkuhria pinnata (species group Z. Table 1) and encroachment by the shrubs Acacia karroo (species group Y, Table 1), Asparagus suaveolens and Asparagus laricinus (species group Z, Table 1) indicate that this sub-community is in a more degraded condition than the Diheteropogon amplectens Grassland Subcommunity (5.2). Another shrub in this subcommunity is the low-growing species Ziziphus zeyheriana (species group EE, Table 1), while the grass species Elionurus muticus (species group CC, Table 1) and Eragrostis chloromelas (species group FF, Table 1) have relatively high cover-abundance values.

The shrub stratum is poorly developed, 0.5 $\mathrm{m}$ tall on average and has an average canopy cover of $8 \%$, while the herbaceous stratum has an average height of $0.8 \mathrm{~m}$ and an average canopy cover of $75 \%$. An average number of 40 species was recorded per sample plot of which only $7 \%$ were introduced and $6 \%$ were therophytes.

Although their diagnostic species are different, the Themeda triandra Grassland Subcommunity of the Schizachyrium sanguineum - Diheteropogon amplectens Grassland Community, seems to be the most similar to the Uryletro agropyroidisSchizachyrietum sanguinei, an association of the Diheteropogono amplectentisSchizachyrion sanguinei, described for the midslopes of the Fb land type (Bezuidenhout et al. 1994c). The high cover abundance values and dominance of the grass species
Themeda triandra and Elionurus muticus are some of the similarities between these two communities.

5.2 Diheteropogon amplectens Grassland Sub-community

This sub-community of the Schizachyrium sanguineum - Diheteropogon amplectens Grassland Community is mainly situated on the higher-lying crests, on shallow soils of the Glenrosa and Mispah soil forms (Fig. 2). This sub-community is associated with soils where rocks and stones comprise more than $30 \%$ of the soil surface (Fig. 4).

The diagnostic species are those of species group AA (Table 1), which include the indigenous forbs Jamesbritten aurantiaca, Pachystigma pygmaeum, and Dicoma anomala, geophytes such as Ledebouria ovatifolia and Gladiolus permeabilis subsp. edulis and the dwarf-shrub Elephantorrhiza elephantina. The indigenous grass Diheteropogon amplectens (species group BB, Table 1) is the dominant species. Other grasses such as Schizachyrium sanguineum, Eragrostis racemosa (species group $\mathrm{BB}$, Table 1) and Themeda triandra (species group FF, Table 1) and the succulent Aloe transvaalensis (species group GG, Table 1) have high cover abundance values. The herbaceous stratum is well developed (average canopy cover of $80 \%$ and average height of $0.8 \mathrm{~m}$ ), while the shrub stratum is only $0.3 \mathrm{~m}$ tall on average and has an average canopy cover of $5 \%$. An average number of 35 species was recorded per sample plot of which only $3 \%$ were introduced and $4 \%$ were therophytes.

The Monocymbio ceresiiformis-Schizachyrietum sanguinei which was described for the high-lying plateaux of the $\mathrm{Fb}$ land type (Bezuidenhout et al. 1994c) is not particularly similar to this sub-community currently described. It is, however, more similar than any of the communities, sub-communities or variants described by Bezuidenhout et al. (1994d) for the Schizachyrium sanguineum - Diheteropogon amplectens Major Grassland Community of the Lichtenburg area. 


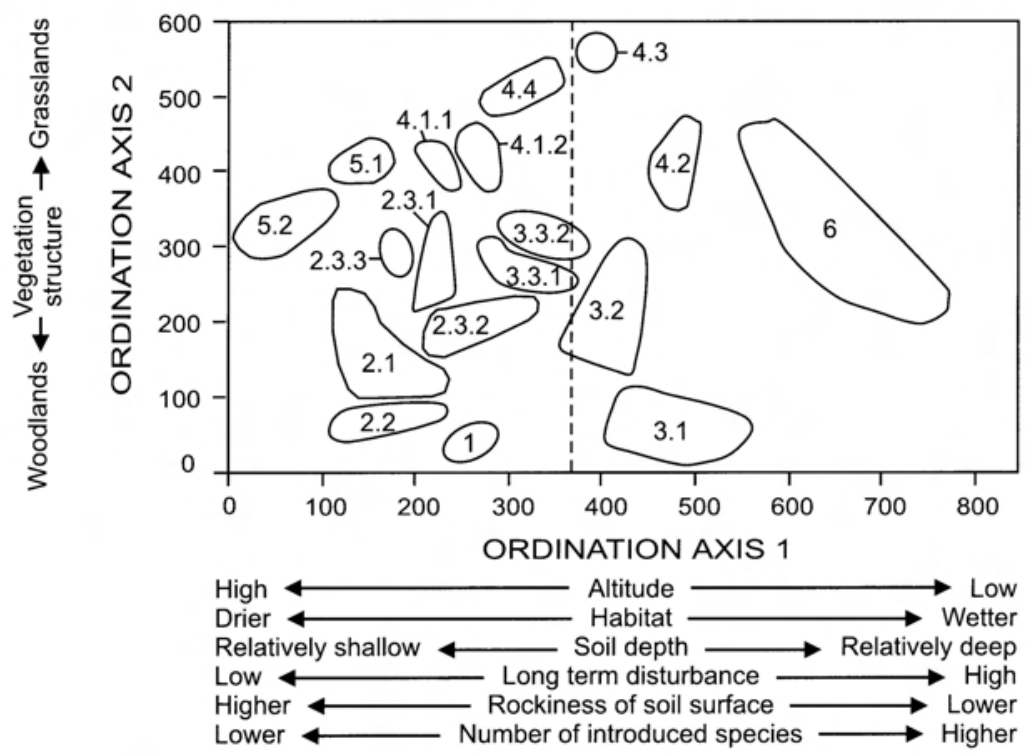

Fig. 5. The relative positions of the natural and degraded natural communities along the first two axes of the ordination of natural and semi-natural areas in the Potchefstroom municipal area, North West Province, South Africa (numbers refer to those in text).

\section{Paspalum dilatatum - Cynodon dactylon} Wetland Community

The Paspalum dilatatum - Cynodon dactylon Wetland Community is situated in fragmented natural areas inside the city which are mown every 8-10 weeks. It does not form part of the Mooi River wetland area studied by Cilliers et al. (1998), but also occurs on seasonally waterlogged soils of the Valsrivier soil form (Fig. 2).

The dominant species is the invasive grass Cynodon dactylon (species group II, Table 1). This community is characterised by the species of species group $\mathrm{HH}$ (Table 1), which include the introduced grass species Paspalum dilatatum, the introduced forbs, Plantago lanceolata and Taraxacum officinale and the indigenous forbs Falckia oblonga, Ranunculus multifidus, Homeria pallida and Rumex lanceolatus. Only a herbaceous stratum is present which is $0.6 \mathrm{~m}$ high on average and has an average canopy cover of
$65 \%$. An average number of 14 species was recorded per sample plot of which $48 \%$ were introduced and $12 \%$ were therophytes.

A similar community, the Cynodon dactylon Variant of the Paspalum dilatatum Sub-community was decribed for wetland areas in Potchefstroom and is probably a degraded form of the Cyperus longus Major Wetland Community (Cilliers et al. 1998).

\section{Ordination}

Although no distinct discontinuities can be observed in the scatter diagram of the distribution of the communities along the first and second axes of ordination, the plant communities are restricted to specific spatial areas in the diagram (Fig. 5). Along the first ordination axis all the communities with a relatively short history of disturbances are situated on the left of the diagram (indicated by a dotted line), while those communities with 
a long history of various disturbances (Communities 3.1, 3.2, 4.2, 4.3 and 6) occur to the right (indicated by a dotted line). Also illustrated on the first ordination axis is a gradient which can be related to altitude, soil depth, rockiness of soil surface and wetness or dryness of the habitat. All the woodland communities are situated at the bottom of ordination axis 2, while most of the grassland communities occur towards the top of the axis.

\section{Concluding remarks}

The results of this study can be used in future as a basis for the development of conservation orientated planning and management programmes for the natural and semi-natural areas of Potchefstroom. The establishment of specific maintenance and management programmes for these areas are extremely important because they are situated next to an area which was recently proposed to be included in a new National Park (Fig. 1). Most of the natural communities such as the Rhus leptodictya - Acacia caffra Woodland Community (2), the Themeda triandra Grassland Community (4) and the Schizachyrium sanguineum - Diheteropogon amplectens Grassland Community (5) described in this study could be related to specific environmental conditions. Variations between the communities could be ascribed to factors such as altitude, terrain type, soil type, soil depth and rockiness of soil surface. The communities are also similar to communities described for natural areas by Bezuidenhout \& Bredenkamp (1991) and Bezuidenhout et al. (1994a, b, c and d) and fulfill, therefore, some of the criteria stated by Smith \& Theberge (1986) as essential in the evaluation of areas for conservation purposes. These criteria include aspects such as naturalness, high species diversity, representativeness and the occurrence of rare species. The rare species mentioned here are for typical grassland species seen in an urban context.
The presence of degraded forms (Communities 2.3.1, 2.3.3, 3.1, 3.2, 4.2 and 4.3) of most of the natural communities described in this study, indicates the influence of various direct or indirect human disturbances on the natural vegetation. The dynamics of these man-induced communities (also called anthropogenic or synanthropic communities by Kornas 1983) must be monitored over the long term, under different types and intensities of direct and indirect human impacts. Information gathered on the different successional stages in the study of vegetation dynamics, will enable city planners, landscape architects and urban ecologists to develop an ecologically sound planning, management and rehabilitation programme for fragmented and other natural and semi-natural areas in the urban environment. It must be emphasised, that these programmes cannot be based on ecological research alone, but also on the incorporation of sociological aspects, as was clearly indicated by Gilbert (1989). The intensity of different direct and indirect human influences in the context that the inhabitants of different cities, towns and suburbs have different needs, should be quantified. It is also necessary to encourage public awareness of the importance of natural and semi-natural urban open spaces, in order to promote an integrated and participatory approach in the conservation of these areas.

\section{Acknowledgements}

The first author wishes to thank the Potchefstroom University for Christian Higher Education for funding this project, Prof. A.J.H. Pieterse, Head of the Section Botany of the School for Environmental Sciences and Development, Potchefstroom University for valuable comments on the text, the National Herbarium, Pretoria and Mr. B. Ubbink, Botanical Garden, Potchefstroom University for plant identification.

\section{References}

ARnold, T.H. \& B.C. DE WET. 1993. Plants of southern Africa: names and distribution. Memoirs of the Botanical Survey of South Africa 62: 1 - 825 . 
Bezuidenhout, H. 1993. Syntaxonomy and Synecology of western Transvaal Grasslands. $\mathrm{Ph}$. D. thesis, University of Pretoria, Pretoria.

Bezuidenhout, H. \& G.J. BredenKamp. 1991. The vegetation of the $\mathrm{Bc}$ land type in the western Transvaal Grassland, South Africa. Phytocoenologia 19(4): 497 - 518.

Bezuidenhout, H., G.J. Bredenkamp \& G.K. THERON. 1994a. Phytosociological classes of the western Transvaal grassland, South Africa. Koedoe 37(1): 1 - 18.

Bezuidenhout, H., G.J. Bredenkamp \& G.K. THERON. 1994b. A classification of the vegetation of the western Transvaal dolomite and chert grassland, South Africa. South African Journal of Botany 60(3): 152 - 161.

Bezuidenhout, H., G.J. Bredenkamp \& G.K. THERON. 1994c. Syntaxonomy of the vegetation of the $\mathrm{Fb}$ land type in the western Transvaal Grassland, South Africa. South African Journal of Botany 60(3): 72 - 81 .

Bezuidenhout, H., G.J. Bredenkamp, G.K. Theron \& J.W. MoRrIS. 1994d. A Braun-Blanquet reclassification of the Bankenveld Grassland in the Lichtenburg area, south-western Transvaal. South African Journal of Botany 60(6): 297-305.

BRedenkamp, G.J. \& G.K. Theron. 1978. A synecological account of the Suikerbosrand Nature Reserve. 1. The phytosociology of the Witwatersrand geological system. Bothalia 12: $513-529$.

Bredenkamp, G.J. \& N. van Rooyen. 1996. Dry Sandy Highveld Grassland. Pp. 41-42. In: Low, A.B. \& A.G. Rebelo, (eds.) Vegetation of South Africa, Lesotho and Swaziland. Pretoria: Dept. Environmental Affairs \& Tourism.

BRedenkamp, G.J., A.F. Joubert \& H. BEZUIDENHOUT. 1989. A reconnaissance survey of the vegetation of the plains in the Potchefstroom-Fochville-Parys area. South African Journal of Botany 55: 199 - 206.

Cilliers, S.S. 1998. Phytosociological studies of urban open spaces in Potchefstroom, North West Province, South Africa. P.hD. thesis, Potchefstroom University for Christian Higher Education, Potchefstroom.

Cilliers, S.S. \& G.J. Bredenkamp. 1998. Vegetation analysis of railway reserves in the Potchefstroom Municipal Area, North West Province, South Africa. South African Journal of Botany 64(5): 271-280.

Cilliers, S.S. \& G.J. BredenKamp (in press a). Ruderal and degraded natural vegetation on vacant lots in the Potchefstroom Municipal Area, North West Province, South Africa. South African Journal of Botany.
Cilliers, S.S. \& G.J. BRedenKamp (in press b). Analysis of the spontaneous vegetation of intensively managed urban open spaces in the Potchefstroom Municipal Area, North West Province, South Africa. South African Journal of Botany.

Cilliers, S.S., L.L. Schoeman \& G.J. BRedenkamp. 1998. Wetland plant communities in the Potchefstroom Municipal Area, North West Province, South Africa. Bothalia 28(2): 213229.

CoHEn, M. \& M.L. Hugo. 1986. Conservation outside of officially designated areas - with emphasis on the urban environment. Parks and Grounds 38: 15 - 23.

Cowling, R.M. \& W.J. Bond. 1991. How small can reserves be? An empirical approach in Cape Fynbos, South Africa. Biological Conservation 58(3): $243-256$.

EDWARDS, D. 1983. A broad-scale structural classification of vegetation for practical purposes. Bothalia 14(3 \& 4): $705-712$.

FRIEDEL, M.H. 1987. A preliminary investigation of woody plant increase in the western Transvaal and implications for veld assessment. Journal of the Grassland Society of southern Africa 4: 25 30.

Fuls, E.R., G.J. BREDENKAMP \& N. VAN ROOYen. 1993. The grassland communities of the footslopes in the northern Orange Free State, South Africa. South African Journal of Botany 59(5): 485 - 490.

GILBERT, O.L. 1989. The ecology of urban habitats. London: Chapman \& Hall.

Henderson, L. 1995. Plant Invaders of southern Africa. Pretoria: Plant Protection Research Institute Handbook No. 5.

HENKE, H. \& H. SUKopP. 1986. A natural approach in cities. Pp. 307 - 324. In: Bradshaw, A.D., D.A. GoodE \& E.H.P. Thorp (eds.). Ecology and Design in Landscape, 1983. 24th Symposium of the British Ecological Society. Oxford: Blackwell.

HenneKens, S.M. 1996a. TurboveG: Software package for input, processing, and presentation of phytosociological data. University of Lancaster: IBN-DLO.

HENNEKENS, S.M. 1996b. Megatab: a visual editor for phytosociological tables. Ulft: Giesen.

Hill, M.O. 1979a. TwinsPan: a Fortran program for arranging multivariate data in an ordered two-way table by classification of individuals and attributes. Ithaca, New York: Cornell University.

Hill, M.O. 1979b. DECORANA: a Fortran program for detrended correspondence analysis and reci- 
procal averaging. Ithaca, New York: Cornell University.

KoOIJ, M.S., J.C. Scheepers, G.J. BRedenkamp \& G.K. Theron. 1992. The vegetation of the Kroonstad area: A description of the grassland communities. South African Journal of Botany 58(3): $155-164$

KoRnAS, J. 1983. Man's impact upon the flora and vegetation in Central Europe. Pp. 277 - 286. In: HOLZNER, W., M.J.A. WERGER \& I. IKUSIMA (eds.). Man's impact on vegetation. The Hague: Junk.

Land Type Survey StafF. 1984. Land types of the map 2626 West Rand and 2726 Kroonstad. Memoirs on the Agricultural Natural Resources of South Africa 4: 1 - 441.

Louw, W.J. 1951. An ecological account of the vegetation of the Potchefstroom area. Memoirs of the Botanical Survey of South Africa 24: 1 - 105.

McDowell, C.R., A.B. Low \& B. McKenzie. 1991. Natural remnants and corridors in Greater Cape Town: their role in threatened plant conservation. Pp. 27 - 39. In: SAunders, D.A. \& R.J. HobBs (eds.). Nature Conservation 2: the role of corridors. Chipping North, Australia: Surrey Beatty.

Mentis, M.T. \& B.T. Huntley. 1982. A description of the Grassland Biome Project. Pretoria: Council for Scientific and Industrial Research, National Scientific Programmes Unit. (South African National Scientific Programmes report; no. 62.)

Mueller-Dombois, D. \& H. Ellenberg. 1974. Aims and methods of vegetation ecology. New York: Wiley.

POYNTON, J.C. \& D.C. ROBERTS. 1985. Urban open space planning in South Africa: A biogeographical perspective. South African Journal of Science 81: 33 - 37.

PYŠEK, P. 1995. Approaches to studying spontaneous settlement flora and vegetation in Central Europe: a review. Pp. 23 - 39. In: Suкорp, H., M. Numata \& A. Huber (eds.). Urban ecology as the basis for urban planning. The Hague: SPB Academic Publishing.

Raunkiaer, C. 1937. Plant Life Forms. Oxford: Clarendon Press.

Rebelo, A.G. \& W.R. Siegfried. 1992. Where should nature reserves be located in the Cape Floral region, South Africa? Models for spatial configuration of a reserve network aimed at maximising the protection of floral diversity. Conservation Biology 6: 243 - 252.
ROBERTS, D.C. 1993a. The vegetation ecology of municipal Durban. Floristic classification. Bothalia 23(2): 271 - 326.

Roberts, D. C. 1993b. D’Moss - Urban ecology in action. Muniviro 10(3) :3 - 16.

Roberts, D.C. \& J.C. Poynton. 1985. Central and peripheral open spaces: need for biological evaluation. South African Journal of Science 81: 464 - 466.

RUtherford, M.C. \& R.H. WestFall. 1994. Biomes of southern Africa: An objective categorization. 2nd ed. Memoirs of the Botanical Survey of South Africa 63: 1 - 94.

SACS. 1980. Stratigraphy of South Africa. Part 1 (comp. L.E. KENT). Lithostratigraphy of the Republic of South Africa, South West Africa/Namibia, and the Republics of Botswana, Transkei and Venda. Pretoria: Dept. Mineral and Energy Affairs.

Smith, P.G.R. \& J.B. Theberge. 1986. A review of criteria for evaluating natural areas. Environmental Management 10(6): 715 - 734.

Soll Classification Work Group. 1991. Soil classification - A taxonomic system for South Africa. 2nd edition. Memoirs on the Agricultural Natural Resources of South Africa 15: 1-262.

SPEllerberG, I.F. 1992. Evaluation and assessment for conservation. London: Chapman \& Hall.

Van Wyk, E., S.S. Cilliers \& G.J. Bredenkamp. 1997. Ranteveldplantegroei van Klerksdorp, Noordwes Provinsie, Suid-Afrika. Die SuidAfrikaanse Tydskrif vir Natuurwetenskap en Tegnologie 16(2): 74 - 85.

Weather Bureau. 1988. Climate of South Africa. Report No. 40. Pretoria: Government Printer.

Wells, M.J., A.A. Balsinhas, H Joffe, V.M. Engelbrecht, G. Harding \& C.H. Stirton. 1986. A Catalogue of problem plants in southern Africa, incorporating the National Weed List of South Africa. Memoirs of the botanical Survey of South Africa 53: 1 - 658.

Wood, J., A.B. Low, J.S. Donaldson \& A.G. REBELO. 1994. Threats to plant species diversity through urbanization and habitat fragmentation in the Cape Metropolitan Area, South Africa. Pp. 259 - 274. In: Huntley, B.J. (ed.) Strelitzia 1, Botanical diversity in southern Africa. Proceedings of a Conference on the Conservation and Utilisation of Southern African Botanical Diversity, Cape Town, September 1993. Pretoria: National Botanical Institute. 